\title{
Ličani u okupaciji Bosne i Hercegovine 1878. godine
}

Nikola Tominac

Zagreb

E-pošta: nikola.tominac@gmail.com
UDK: 94(497.6)"1878"

Pregledni rad

Primljeno: 26. veljače 2020

Prihvaćeno: 10. lipnja 2020.

\section{Sažetak}

Kao veoma važno povijesno događanje našega šireg okružja pomalo je zaboravljena okupacija Bosne i Hercegovine iz 1878. godine koja je vojnom prisilom potpuno promijenila političko stanje ove osmanske pokrajine, prouzročivši usput brojne žrtve s obje zaraćene strane. Za pojedine građane tadašnje Bosne $\mathrm{i}$ Hercegovine to je bila velika tragedija, a za druge sreća zbog postizanja neovisnosti od osmanske vlasti. Iako su se ovi događaji dogodili prije više od 140 godina, njihove posljedice su i dalje vidljive i ne ćemo ih razumjeti ako ne upoznamo to vrijeme, a posebno političke okolnosti u kojima se sve to dogodilo. Nadamo se da će ovaj prilog, koji je posvećen Otočkoj pješačkoj pukovniji br. 79 - Otočaner Linien-Inftanerie-Regiment Graf Jellačić Nr. 79., omogućiti čitateljima da bolje razumiju kako se ovaj dio Europe preoblikovao kroz povijest. Posebno je to važno iz razloga što se kod pojedinih naroda ti događaji različito pamte i tumače. Time će taj tragični period postati dio našega povijesnog sjećanja i za bolje shvaćanje današnjice i budućnosti.

Treba napomenuti da je 79. pješačka pukovnija nastala na području nekadašnjih četiriju narodnih graničarskih pješačkih pukovnija (regimenti) - National-Grenz-Infanterie-Regiments - iz sastava Karlovačkog generalata: Ličke (Gospić), Otočke, Ogulinske i Slunjske. Iako Slunj i Ogulin ne pripadaju području Like kao zemljopisnoj i povijesnoj hrvatskoj regiji, vojnici ove pukov- 
nije nosili su lički regionalni predznak. Naime, kroz njezinu daljnju povijest, osobito Prvi svjetski rat, smatrana je ličkom pukovnijom i kao takva vojno je proslavila ovu regiju.

Ključne riječi: okupacija Bosne i Hercegovine 1878.; Bihać; Otočka linijska pješačka pukovnija grof Jelačić br. 79.

\section{Uvod}

Ovaj je prilog posvećen obilježavanju 140. obljetnice okupacije Bosne i Hercegovine i pripadnicima ličke 79. pješačke pukovnije grofa Jelačića iz Otočca (Ungarisches (croatisches) Otočaner Infanterie-Regiments Graf Jellačić Nr. 79), ${ }_{1}^{1}$ poznatije kao "Jelačićevci" koja je imala najveće gubitke u okupaciji, a Bihać je bio poprište borbi s međusobno najvećim gubitcima. "Jelačićevci" su u jednom danu (7. rujna 1878.) imali ukupne gubitke od 317 vojnika. ${ }^{2} \mathrm{U}$ njemu je opisano njihovo sudjelovanje u vojnim operacijama na području zapadne i srednje Bosne. Ovime želimo odati počast velikim žrtvama pukovnije u tim operacijama, ali i svim ostalim sudionicima ovih događanja. Da bi se shvatila isprepletenost interesa velikih sila oko same okupacije, navedeni su vojno-politički odnosi Osmanske države, a posebno Habsburške Monarhije, te odnosi na širem okružju.

$\mathrm{Na}$ temelju raspoložive literature i izvorne arhivske građe iz fundusa Austrijskoga Ratnog arhiva - Österreichisches Staatsarchiv Kriegsarchiv, prvenstveno iz sačuvane operativne dokumentacije, sačinjena je analiza borbi u kojima je sudjelovala lička pukovnija. Posebno je bilo dragocjeno veoma rijetko sačuvano djelo Carla Schmarde, Kurzgefasste Geschichte des k.u.k. Otočaner Infanterie-Regiment Graf Jellačić Nr. 79 und seiner Stammregimenter. Im Auftrage des herrn K.und K. Obersten und Regiments-Commandanten $\mathrm{He}$ inrich Hennevogl von Ebenburg, koje opisuje sudjelovanje Ličana u ovim operacijama i predstavlja izniman izvor vrlo važnih podataka o povijesti pukovnije, te nezaobilazna vojna analiza bojeva iz Die

1 Kais. Königliche Militär Schematismus für 1879, Aus der k.k. Hof-und Staatsdruckerei, Wien, 1878., str. 394.

2 Die Occupation Bosniens und der Herzegovina durch K.K. Truppen im Jahre 1878, nach autentischen Quellen, Verlag des k.k. Generalstabes, Wien, 1879., Prilog 12. 
Occupation Bosniens und der Herzegovina durch K.K. Truppen im Jahre 1878, nach autentischen Quellen, koju je izdao austrougarski Generalštab tijekom 1879. godine u Beču. Također su zanimljiva sjećanja topničkoga natporučnika Aleksandra Milenkovića, glavnostožernoga časnika u 72. pješačkoj brigadi: "Bihać und Kladuš. Meine Errinerungen als Oberleutnant und Brigadegeneralstabsoffizier aus der Okkupation Bosniens im Jahre 1878", objavljena u bečkim novinama Danzer's Armee-Zeitung, broj: 51/52, iz prosinca 1911. godine. ${ }^{3}$

Vojna terminologija prilagođena je sadašnjoj službenoj hrvatskoj terminologiji, a tamo gdje to nije bilo moguće, navedeni su usporedno sadašnji hrvatski i austrijski pojmovi, osobito za vojne činove i formacije.

\section{Uspon i pad Osmanskoga Carstva}

Raspad velike države donosi dugotrajni kaos. Što je država moćnija i uspješnija, kaos je utoliko veći i dugotrajniji. Propast Rimskoga Carstva Europu je doslovce deciviliziralo i stavio je u dugotrajnu krizu identiteta. Za našu je temu važan raspad Osmanskoga Carstva. Zbog golema interesa pojedinih velesila na tom području, osobito oko prevlasti nad vrlo važnim energentima i strategijskim komunikacijama, taj je raspad iza sebe ostavio kaos.

A sve je zapravo započelo tijekom 7. stoljeća kada je svoj pobjednički pohod započeo islam. Njegovo širenje je za kršćanski Zapad značilo katastrofu svjetskopovijesnih dosega. Kršćanstvo nestaje u sjevernoj Africi, ali i na drugim do tada iskonskim kršćanskim područjima poput Palestine, Sirije i Egipta. Kao jedina ozbiljna sila na Zapadu preostala je Katolička crkva, nasljednica kasnoantičke državnosti i organizacije koja će dominirati svekolikim kulturnim životom. Međutim, zbog njezina nejedinstva i unutarnjih raskola, posebno vjerskih ratova i inkvizicije, dovest će do dramatičnih posljedica u njezinu djelovanju. ${ }^{4}$

3 U obradi izvorne građe i njezinu prevođenju upućujem posebnu zahvalu gospodinu Lovri Galiću, dipl. ing. iz Zagreba, dr. sc. Milanu Vrbanusu i dr. sc. Vijoleti Herman Kaurić iz Hrvatskoga instituta za povijest, stožernom naredniku Tomislavu Cvjaku na prijevodima, pok. dr. sc. Jozefu Jerku iz Beča na prikupljanju arhivske građe u Ratnom arhivu u Beču, te mag. nov. Anti Livajiću iz Nacionalne i sveučilišne knjižnice iz Zagreba, pukovniku Jozi Staniću, dr. sc. Petru Bagariću i prof. Želimiru Prši.

4 Hans KüNG, Katolička crkva, kratka povijest, ALFA, Zagreb, 2007., str. 92-93, 96, 191. 
Nastankom Islamskoga emirata na području Male Azije, kojeg je utemeljio Gazi Osman godine 1288., doživjet će višestoljetni zadivljujući uspon. Osmanovi nasljednici širit će državu daleko izvan svoje postojbine. Mehmed II. Osvajač godine 1453. osvaja Konstantinopolis, a uskoro vazalne zemlje jugoistočne Europe izravno je uključio u svoju državu. Osvajanjem Beograda 1521. godine otvorili su se strateški pravci prodora prema srednjoj Europi. Poslije bitke na Mohačkom polju 1526. godine zauzeti su dijelovi Ugarske i Hrvatske. Godine 1529. nastupa neuspješna prva opsada Beča, 1541. pao je Budim, 1566. nastupa opsada Sigeta, i nakon toga će se Osmansko Carstvo naći na vrhuncu svoje moći. Tijekom 16. i 17. stoljeća postaje jedna od najmoćnijih država na svijetu. Prostiralo se od Crvenoga mora do Krima i od Kurdistana do Bosne. Imalo je do 14.000 .000 stanovnika. U to su vrijeme Osmansko Carstvo i Kina bili primjeri civiliziranoga življenja koje su Europljani sa zavišću i poštovanjem mogli promatrati. ${ }^{5}$

Jednako neočekivano kao što je izraslo u svjetsku velesilu Osmansko Carstvo počelo se urušavati. Nagrizali su ga brojni unutarnji odnosi i neprilagodba civilizacijskim i tehnološkim tekovinama koje su se počele razvijati na Zapadu. Već nakon smrti sultana Sulejmana I. Veličanstvenog 1566. godine Osmansko je Carstvo počelo padati u ozbiljnu krizu.

Vrijeme od 1500. do 1815. bilo je prijelazno razdoblje svjetske povijesti u kojem se europsko društvo približavalo svojoj industrijskoj budućnosti i veliku preobražaju. Pokrenuta znanstvena revolucija omogućila je dotad nezamisliv stupanj nadzora nad prirodom i njezinim bogatstvima. Nakon druge podjele Poljske iz siječnja 1793. godine nastale su velike i moćne države poput Rusije i Austrije koje su dovele osmansku državu u poluokruženje sa sjevera i zapada. Središnja osmanska vlast, koja je upravljala golemom državom raširenom na tri kontinenta, postajala je sve slabija. Da bi pokušala dosegnuti uspon Zapada, ona se pokušava reformirati i doći do potpuno novoga društvenog, privrednog, obrazovnog, duhovnog i političkog državnog ustrojstva, ali se tome žestoko protive povlaštene strukture što je dovelo do brojnih pobuna širom Carstva.

5 The Times Atlas of World History, revised edition, Times Book Limited, London, 1984., prijevod za Jugoslaviju, Cankarjeva založba, Ljubljana, 1986., str. 170. 


\section{2. "Istočno pitanje" i njegove posljedice}

Navedenim jačanjem Zapada polako dolazi do većih poraza Osmanlija: njihove flote kod Lepanta (1571.), bitke kod Siska (1593.) i Dugim ratom s Austrijom (1593.-1606.). U ratu na dvije fronte, s Perzijom na istoku i Austrijom na zapadu, sultan Ahmed I. morao je formalno odustati od dubljih prodora u Europu, i mirom na rijeci Žitvi iz 1606. prihvatit će teritorijalni status quo. ${ }^{6} \mathrm{U}$ nastavku će doći do bitke kod St. Gottharda (Monoštra) na Rabi 1664. godine i ponovnoga pokušaja osvajanja Beča 1683. pod velikim vezirom Kara Mustafom, što je dovelo do tzv. Bečkog (Velikog) rata (1683.-1699.) i to je bila posljednja veća osmanska napadna operacija. Da bi se zaštitili od mogućih novih osmanskih iznenađenja, godine 1684. dolazi do stvaranja kršćanske Svete lige i serije teških osmanskih poraza poput Mohača (1687.), Slankamena (1691.) i Sente (1697.). ${ }^{7}$ Osmanlije su mirom u Srijemskim Karlovcima 1699. prihvatili gubitak Ugarske do Temišvara, Erdelja, zapadne Ukrajine i Podolja, Moreje, dio Dalmacije, Slavonije i Hrvatske do Une, te područja južno od Velebita. To je bilo prvo veće osmansko povlačenje na ovim prostorima. ${ }^{8}$

6 Mir na rijeci Žitvi, mirovni ugovor između Habsburške Monarhije i Osmanskoga Carstva zaključen 11. studenoga 1606. na ušću rijeke Žitve u Dunav. To je bio prvi mirovni sporazum između ta dva carstva u kojem su hrvatskougarski kralj i osmanski sultan bili ravnopravni pregovarači. Od toga trenutka habsburški vladari prestali su plaćati danak Turcima. Po završetku Dugoga rata (Trinaestogodišnji rat), koji je započeo bitkom kod Siska 1593. godine, počeli su pregovori o miru između Habsburške Monarhije i Osmanskoga Carstva. Tim mirom zapravo je prihvaćen status quo jer je svaka strana zadržala one prostore koje je osvojila tijekom rata, te je dogovoreno da se na granici ne smiju podizati nove utvrde. Habsburzima su ovim mirom pripale utvrde Čazma, Petrinja, Moslavina, Gora i Hrastovica.

7 Sveta liga iz 1684. bila je drugi savez istoga imena poput ranije Svete lige iz 1571. koja nije dovoljno zaživjela u praksi. Osnovana je od tadašnjih graničnih i najugroženijih europskih zemalja prema Osmanskom Carstvu na poticaj pape Inocenta XI. Ligu su osnovali: Sveto Rimsko Carstvo, Mletačka republika i Poljsko-litavska unija. Rusko Carstvo pridružilo se Ligi dvije godine kasnije 1686. godine, i to je bilo prvi put da se Rusija uključila u neku europsku asocijaciju. Ovaj savez osnovan je prije svega da se vojno suprotstavi Osmanskom Carstvu u Velikom turskom ratu, trajao je do potpisivanja Mira u Srijemskim Karlovcima 1699.

8 http://www.enciklopedija.hr/natuknica.aspx?id=45716, Hrvatska enciklopedija, Osmansko Carstvo (7. 11. 2019.). 
Ovako velik gubitak osmanskog teritorija otvorio je brojna interesna pitanja velikih sila toga vremena što je dovelo do otvaranja tzv. Istočnog pitanja. To će obilježiti međunarodne odnose od kraja 18. pa sve do početka 20. stoljeća izazvanih borbom velikih sila i pojedinih naroda poput Habsburške Monarhije, Rusije, Francuske, Velike Britanije, Njemačke i Italije nakon ujedinjenja, te Grčke za stjecanjem svojih interesa. Tako je interes Habsburške Monarhije bio usmjeren na jugoistočnu Europu, gdje se sukobljava s Rusijom, a ruski prevladavajući interes bilo je Crno more s morskim prolazima u Sredozemno more te područje Kavkaza i dijelova Perzije. Francuskoj je bio važan Bliski istok, posebno sirijska obala i zaleđe (današnji Libanon i Sirija) i sjeverne obale Sredozemnoga mora. Sredozemlje, morski tjesnaci, Irak, Palestina i dio Perzije bili su interesno područje Velike Britanije.

Tijekom 18.-20. stoljeća u Europi je nacionalizam zamijenio duhovnost i odanost vjeri što je dovelo do militarizacije pojedinih društava i na kraju uzrokom dvaju katastrofalnih svjetskih ratova. ${ }^{9}$

U prvoj polovici XIX. stoljeća prevladavaju Napoleonovi ratovi, restauracija i revolucionarna kretanja koja završavaju intenzivnom industrijalizacijom koja je stubokom promijenila gospodarske odnose u Europi. To je vrijeme borbi Velike Britanije i Francuske za prevlast u svijetu i početak industrijske revolucije. Težište europskih sukoba prebacuje se dijelom na europski prostor, tako da je intenzitet borbi s Osmanlijama umanjen osim Habsburško-osmanskog rata vođenog 1787. do 1791. koji je doveo do Svištovskog mira ${ }^{10}$ kada se austrijska

9 Karen Armstrong, Islam, kratka povijest, ALFA, Zagreb, 2008., str. 247.

10 Svištovski mir između Osmanskoga Carstva i Habsburške Monarhije potpisan je 4. kolovoza 1791. Naziv je dobio prema gradu Svištovu, u kojem je zaključen, a koji se nalazi na području današnje Bugarske. Svištovskim mirom završen je Habsburško-osmanski rat, koji je trajao od 1787. do 1791. godine, velikim dijelom usporedo s Rusko-osmanskim ratom koji je protiv Osmanskoga Carstva vodila ruska carica Katarina Velika. Prema odredbama Svištovskog mira Habsburškoj Monarhiji pridodana su neka granična hrvatska područja poput mjesta Cetin, Drežnik, Lapac i Srb, kao i pojas zemljišta pokraj Plitvičkih jezera. Osim navedenoga, Habsburška Monarhija dobila je tim mirom i područje grada Oršave na Dunavu, na prostoru današnje Rumunjske. Ratom osvojena naselja Bosanski Novi, Bosanska Dubica i Bosanska Gradiška, Beograd, te osvojeni dijelovi Srbije bili su vraćeni Osmanskomu Carstvu. Radilo se o malim teritorijalnim dobitcima, tako da Habsburška Monarhija nije u potpunosti iskoristila svoje vojne uspjehe. Na takvo je popuštanje bila prisiljena, 
politika težišno prebacuje na prostor jugoistočne Europe pod osmanskom vlašću. Tako intenzivna događanja i promjene stvorile su sasvim nove političke odnose vezane za sudbinu sve slabijega Osmanskog Carstva.

Napoleon je 1801. godine bio zainteresiran da s Habsburzima podijeli Osmansko Carstvo. Međutim, uskoro dolazi do međusobnoga vojnog sukoba i pobjede Francuza. Produkt toga rata je Požunski mir ${ }^{11}$ iz 1805. godine kojim je Austrija morala dati Francuskoj Dalmaciju s Bokom kotorskom. Napoleon je planirao uz pomoć povoljnog saveznika pokrenuti rat protiv Osmanlija, čim mu to omoguće raspoloživi resursi. Austrijance je zabrinjavala pomisao da taj saveznik bude Rusija iako je ona u to vrijeme bila u ratu s Napoleonom. Naprotiv, Ruse je pak zanimao savez s Austrijom u borbi protiv Napoleona. Oni su bili voljni nakon pobjede nad Francuzima Austrijancima prepustiti Dalmaciju, Srbiju, Bosnu i Hercegovinu. ${ }^{12}$

\section{Berlinski kongres}

Nakon konačnog poraza Napoleona 1815. godine Rusko Carstvo doživljava intenzivnu ekspanziju i modernizaciju i time postaje najjača sila u Europi. Svojim širenjem dolazi u sve veći sukob s britanskim interesima koji se protive gotovo svakom ruskom širenju. To se posebno odnosi na područje jugoistočne Europe, a posebno na

između ostaloga, zbog toga što je u međuvremenu izbila Francuska revolucije pa se austrijska vojna sila morala spremati za ratove na suprotnom dijelu Europe. Izvor: https://www.enciklopedija.hr/Natuknica.aspx?ID=59096, Hrvatska enciklopedija, Svištovski mir (7. 11. 2019.).

11 Požunski mir je mirovni ugovor između Austrije i Francuske zaključen 26. prosinca 1805. u Požunu (Bratislava) nakon austrijskog poraza pokraj Ulma (25. rujna - 20. listopada) i Austerlitza (2. prosinca). Austrija se odrekla posjeda stečenih Campoformijskim mirom (Venecija, Istra /bez Trsta/, Dalmacija i Boka kotorska), koji su, osim Boke kotorske, ušli u sastav Kraljevine Italije. Bavarskoj je ustupila Tirol (s Vorarlbergom, Trientom i Brixenom), a Badenu i Württembergu habsburške posjede u Švapskoj. Obvezala se na plaćanje ratne odštete u iznosu od 40,000.000 zlatnih franaka, a zauzvrat bila joj je dopuštena aneksija Salzburga s Berchtesgadenom. Francuska je stekla Pijemont, Parmu i Piacenzu. Požunski mir bio je dokinut na Bečkom kongresu 1814.-1815. Izvor: https://www.enciklopedija.hr/Natuknica.aspx?ID=49908, Hrvatska enciklopedija, Požunski mir (7. 11. 2019.).

12 FERdo ŠIšić, Kako je došlo do okupacije a onda do aneksije Bosne i Hercegovine (1878. odnosno 1908.), Matica hrvatska, Zagreb, 1938., str. 10-12. 
Crno more, te na sjevernu i središnju Aziju i Daleki istok. Mijenja se širi politički kontekst odnosa u Europi, osobito nakon Bečkoga kongresa ${ }^{13}$ i Ugovora iz Pariza 1815. godine. Habsburška Monarhija i Osmansko Carstvo više nisu bile države u ratu nego su kao vanjskopolitičku orijentaciju prihvatile načelo statusa quo. Ovako velika promjena odnosa leži u činjenici da je Monarhiju pomalo sustizala sudbina Osmanskoga Carstva. Postala je besprijekorni branitelj novoga poretka i odnosa ravnoteže među velikim silama. Tijekom Krimskog rata između Rusije i Osmanskoga Carstva (1853.-1856.) za prevlast na jugoistoku Europe, Dardanelima i Bliskom istoku u rat su se na strani Osmanskoga Carstva uključile Austrija i Pruska. Takva se politika zadržava sve do sredine 19. stoljeća kada dolazi do nacionalnih revolucija (1848.-1871.), koje su dovele do talijanskog ujedinjenja 1861., te stvaranja Njemačkog Carstva 1871. godine. Novim odnosom snaga bitno je umanjena važnost Habsburške Monarhije kao velike sile u središnjoj Europi.

Nakon gubitka rata s Pruskom u bitci kod Sadove 1866. završen je kratki austro-pruski rat potpunim porazom Austrije. Time je propalo nastojanje Habsburgovaca da preuzmu prevlast u njemačkim zemljama. Bismarck je 1867. stvorio Sjevernonjemački savez i obrambenim sporazumima vezao južne njemačke države uz Prusku. Nakon toga dolazi do povijesnog sporazuma između Austrije i Ugarske utvrđenog Austro-ugarskom nagodbom. Tim su državnopravnim aktom iz 1867. uređeni novi odnosi između zemalja pod vlašću Habsburgovaca i stvaranja Austro-Ugarske Monarhije. Nagodba je bila rezultat kompromisa između austrijskih i mađarskih vladajućih krugova. Nakon gubitka Šlezije, Lombardije i Venecije tijekom 1866. pitanje prostora Bosne i Hercegovine za Austriju počinje biti veoma važno pitanje.

13 Bečki kongres bio je skup predstavnika glavnih europskih političkih sila koji se održao u Beču od 1. rujna 1814. do 9. lipnja 1815. Nakana kongresa bilo je uređenje novih granica na političkoj karti Europe nakon vojnog poraza Napoleonove Francuske. Rasprava je bila u tijeku i u vrijeme Napoleonova povratka iz izgnanstva i njegova ponovnog preuzimanja vlasti u Francuskoj, u ožujku 1814. Konačni dokument kongresa potpisan je devet dana prije Napoleonova poraza u bitci kod Waterlooa. Kongres se bavio oblikovanjem Europe nakon Napoleonskih ratova. Temeljni cilj velikih sila bio je obnova političkih odnosa, osobito obnova država koje su u Europi postojale prije Napoleonovih ratova i vraćanje na vlast prognanih kraljevskih dinastija. Austrija je ponovo dobila nadzor nad Tirolom i Salzburgom, ilirskim pokrajinama i područjem Lombardije i Venecije. Izvor: https://www.enciklopedija.hr/Natuknica. aspx?ID=6546, Hrvatska enciklopedija, Bečki kongres (7. 11. 2019.). 
Istovremeno, rastom moći ruski car godine 1744. proglašava se zaštitnikom pravoslavnih kršćana u Osmanskom Carstvu, te baštinikom Bizantskoga Carstva tako da Slaveni pravoslavne vjere ulaze u sferu njegova utjecaja. ${ }^{14}$ Zbog toga se u zemljama Osmanskoga Carstva provlače sve snažniji nacionalizmi. Ustanci slavenskih i drugih neturskih naroda, osobito Srba, Grka, Rumunja i Bugara prerasli su u vrlo ozbiljnu "balkansku krizu". Velike sile pomalo uviđaju da je pojedine narode drugih vjera potrebno izdvojiti iz Osmanskoga Carstva kako bi se spriječilo širenje nacionalnih ustanaka na okolna područja. Prvo su se 1804., pobunili Srbi i do 1830. izborili se za veoma široku autonomiju. To će ubrzo dovesti do rasta nacionalizma slavenskih naroda i u Bosni i Hercegovini. Srpski ustanci i narodna svijest na bazi pravoslavlja s jedne, te Ilirski pokret i ideje narodnog jedinstva svih Južnih Slavena pod vodstvom katoličkih Hrvata s druge strane postaju važne odrednice za budućnost ovih prostora. Zbog toga se u Bosni i Hercegovini pravoslavni Bosanci i Hercegovci sve više okreću prema Srbiji i Crnoj Gori, katolici pod vodstvom franjevaca prema Austriji, a muslimani prema Carigradu. U postupku stjecanja samostalnosti Srbije i Crne Gore rastu njihove aspiracije na Bosnu i Hercegovinu. To se posebno pokazalo 1853. godine tijekom crnogorsko-turskog rata kada je na granicama Bosne i Hercegovine koncentrirana jača austrougarska oružana sila od 69.830 vojnika pod zapovjedništvom hrvatskoga bana Josipa baruna Jelačića, ali se zbog sporazuma s Portom i povlačenja turske vojske iz Crne Gore odustalo od vojnih operacija. Time je spašena Crna Gora od turskog poraza. ${ }^{15}$

Zbog veoma teškog socijalnog stanja, raširene korupcije vladajućih elita, porasta kriminala i krajnje bijede, Bosnom i Hercegovinom se šire brojne bune. Poznate su Pop-Jovičina buna na širem području Dervente iz 1834. godine, hercegovački ustanci pod vodstvom Luke Vukalovića u nekoliko navrata od 1852. do 1862., Posavske bune 1857.-1858., Pecijina buna u Bosanskoj krajini 1858., a posebno je bio brutalan Bosansko-hercegovački ustanak 1875.-1878. koji je pokazao svu nemoć Osmanlija da završe krize i veoma teško socioekonomsko stanje u državi. ${ }^{16}$ Tijekom toga ustanka na područje Hrvatske izbje-

14 F. ŠIšić, Kako je došlo do okupacije a onda do aneksije Bosne i Hercegovine, str. 8-9.

15 Isto, str. 15-16.

16 Vojna enciklopedija, sv. 1, Vojnoizdavački zavod, Beograd, ${ }^{2} 1970$., str. 770; MIHovil Mandić, Povijest okupacije Bosne i Hercegovine 1878, Matica hrvatska, Zagreb, 1910., str. 10-12. 
glo je oko 100.000 ljudi. ${ }^{17}$ Istodobno su zabilježene i brojne bune muslimana koji nisu bili zadovoljni pojedinim reformskim odlukama središnjih vlasti. Tako se 1831. buni dio bosanske političke elite pod vodstvom kapetana Gradačca Husein-bega Gradaščevića ${ }^{18}$ s ciljem stjecanja autonomije za Bosnu i Hercegovinu i zaustavljanje sultanovih reformi. No, ustanak je ubrzo ugušen.

Osmansko Carstvo bilo je suočeno s teškom gospodarskom krizom uzrokovanom naplatom mnogobrojnih inozemnih zajmova. To je prisililo Carstvo da 1875. proglasi bankrot i postane potpuno ovisno o engleskom i francuskom kapitalu. To će dovesti do kaosa na širem prostoru jugoistočne Europe. Godine 1876. Srbija pokušava s vojskom upasti u Bosnu i Hercegovinu što bi još više zakompliciralo političko stanje u toj pokrajini. Zbog toga je Austro-Ugarska ojačala svoje snage uz granicu. Sukob Srba i Osmanlija završio je Carigradskom konferencijom (12. prosinca 1876.) na kojoj su se velike sile pokušale dogovoriti o uvjetima za mir između Osmanskoga Carstva, Srbije i Crne Gore, te o autonomnom statusu Bosne i Hercegovine i Bugarske. Ti pregovori nisu uspjeli zbog velikoga protivljenja Porte, zbog čega nastupa Tursko-ruski rat iz 1877.-1878. u koji se uplelo više velikih sila. ${ }^{19}$

17 Zdravko Dizdar, "Velikosrpska politika prema Lici u 19. i 20. stoljeću", u: Identitet Like, korijeni i razvitak, knjiga I., Institut "Ivo Pilar", područni centar Gospić, Zagreb - Gospić, 2009., str. 633-634; M. Mandić, Povijest okupacije Bosne i Hercegovine 1878, str. 13.

18 Husein-beg Gradaščević (Gradačac, 1802. - Carigrad, 30. ili 31. srpnja 1833.), kapetan Gradačačke kapetanije postao je 1821. Nakon neuspjeha Osmanlija u ratu s Rusijom (1828.-1829.) bosanski se begovat počeo odlučnije protiviti reformama sultana Murata II. i na sastanku bosanskih prvaka u Tuzli na početku 1831. za vođu autonomnoga pokreta u Bosni i Hercegovini bio je predložen kapetan Gradaščević. Tomu su se usprotivili hercegovački prvaci (Smail-aga Čengić i Ali-aga Rizvanbegović). Na početku 1831. Gradaščević je osvojio Travnik i zahtijevao da sultan obustavi provođenje reformi. U srpnju te godine pobijedio je osmansku vojsku kraj Lipljana (Kosovo) i proglasio se bosanskim vezirom, što mu Porta nikada nije potvrdila. Budući da se odbio pokoriti sultanu, ovaj ga je potkraj travnja 1832. proglasio odmetnikom i vojno porazio u bitkama kod Pala (29. svibnja) i Zlog Stupa (4. lipnja). Gradaščević je s članovima obitelji prešao na austrijsko područje. Na Metternichovu intervenciju bio je pomilovan, prešao u Beograd 13. listopada 1832. i predao se tamošnjemu veziru. Iz Beograda je početkom prosinca 1832. otišao u Carigrad, odakle je trebao poći u internaciju, ali je u međuvremenu umro. Izvor: https://www.enciklopedija.hr/Natuknica.aspx?ID=22958, Hrvatska enciklopedija, Gradaščević, Husein beg (7. 11. 2019.).

19 M. Mandić, Povijest okupacije Bosne i Hercegovine 1878, str. 12-13. 
Nakon Tursko-ruskog rata i niza inicijativa političko rješenje za Bosnu i Hercegovinu konačno je dobilo završnu formu Sanstefanskim mirom sklopljenim 3. ožujka 1878. između Rusije i Osmanskoga Carstva u Sanstefanu (danas Yeşilköy pokraj Istanbula). Koristeći se prednošću pobjede, Rusija je zaključenjem toga bilateralnog sporazuma pokušala riješiti problem Istočnoga pitanja u svoju korist stavljajući jugoistočnu Europu pod svoje interesno područje. Ugovorom je zaključeno da se Crnoj Gori, Srbiji i Rumunjskoj prizna neovisnost i teritorijalno proširenje na štetu Osmanskoga Carstva. Stvorena je Velika Bugarska, autonomna kneževina, ali u formalnom vazalnom odnosu prema Osmanskomu Carstvu, koju je u stvarnosti kontrolirala Rusija. Za Bosnu i Hercegovinu bila je predviđena autonomija pod nadzorom Austro-Ugarske i Rusije. Sanstefanskome miru žestoko su se usprotivile velike sile, osobito Velika Britanija i AustroUgarska, zbog velike prevlasti koju je pružao Rusiji. To se posebno odnosilo na mogućnosti njezina izlaska preko Bugarske na Sredozemno more. ${ }^{20}$ Stanje između velikih sila dramatično se zaoštrava.

Zbog ozbiljnosti stanja ubrzo je sazvan Berlinski kongres. Na njemu se sastalo sedam velesila: Engleska, Rusija, Turska, Austro-Ugarska, Njemačka, Francuska i Italija. Donesene su odluke koje su označile novi poredak na jugoistoku Europe. Tako su se prijašnje pretenzije Austro-Ugarske za širenjem na jugoistok Europe konačno i ostvarile. Određeno je da Austro-Ugarska može vojno okupirati područje Bosne i Hercegovine, osim sandžaka Novi Pazar, koji je ostao pod osmanskom vlašću. Dogovoreno je da se austrougarska i turska vlada o potankostima okupacije direktno sporazume. Berlinskom kongresu prethodio je tajni sporazum iz 1877., kojim je carska Rusija dala odriješene ruke Austro-Ugarskoj za okupaciju Bosne i Hercegovine što je pak bilo protivno srpskim interesima. Jedan od osnovnih zadataka okupacije bilo je rješavanje teškoga gospodarskog i političkog stanja i povratka brojnih izbjeglica u Bosnu i Hercegovinu iz ustanaka između 1834.-1878. ${ }^{21}$

20 F. Šıšıć, Kako je došlo do okupacije a onda do aneksije Bosne i Hercegovine, str. 55-56.

21 Vojna enciklopedija, sv. 6, Vojnoizdavački zavod, Beograd, ${ }^{2}$ 1973., str. 360-361; M. Mandić, Povijest okupacije Bosne i Hercegovine 1878, str. 19-20. 


\section{Okupacija Bosne i Hercegovine}

\subsection{Strategijski ciljevi okupacije}

Strategijski ciljevi okupacije Bosne i Hercegovine bili su za AustroUgarsku veoma važni u sklopu sagledavanja općeg stanja na jugoistoku Europe ali i na širem području. Naime, položaj Monarhije u odnosu na zaleđe jugoistočne Europe bio je prije okupacije veoma nepovoljan, osobito za obranu Dalmacije. Dužina granice prema Bosni i Hercegovini i Crnoj Gori iznosila je oko 900 kilometara. Trećina granice išla je dolinom rijeke Save i ona je kao prirodna granica bila pogodna za obranu, dok je ostatak bio vrlo teško branjiv zbog nepovoljnog brdsko-planinskog reljefa. Niti jedna važnija geostrateška

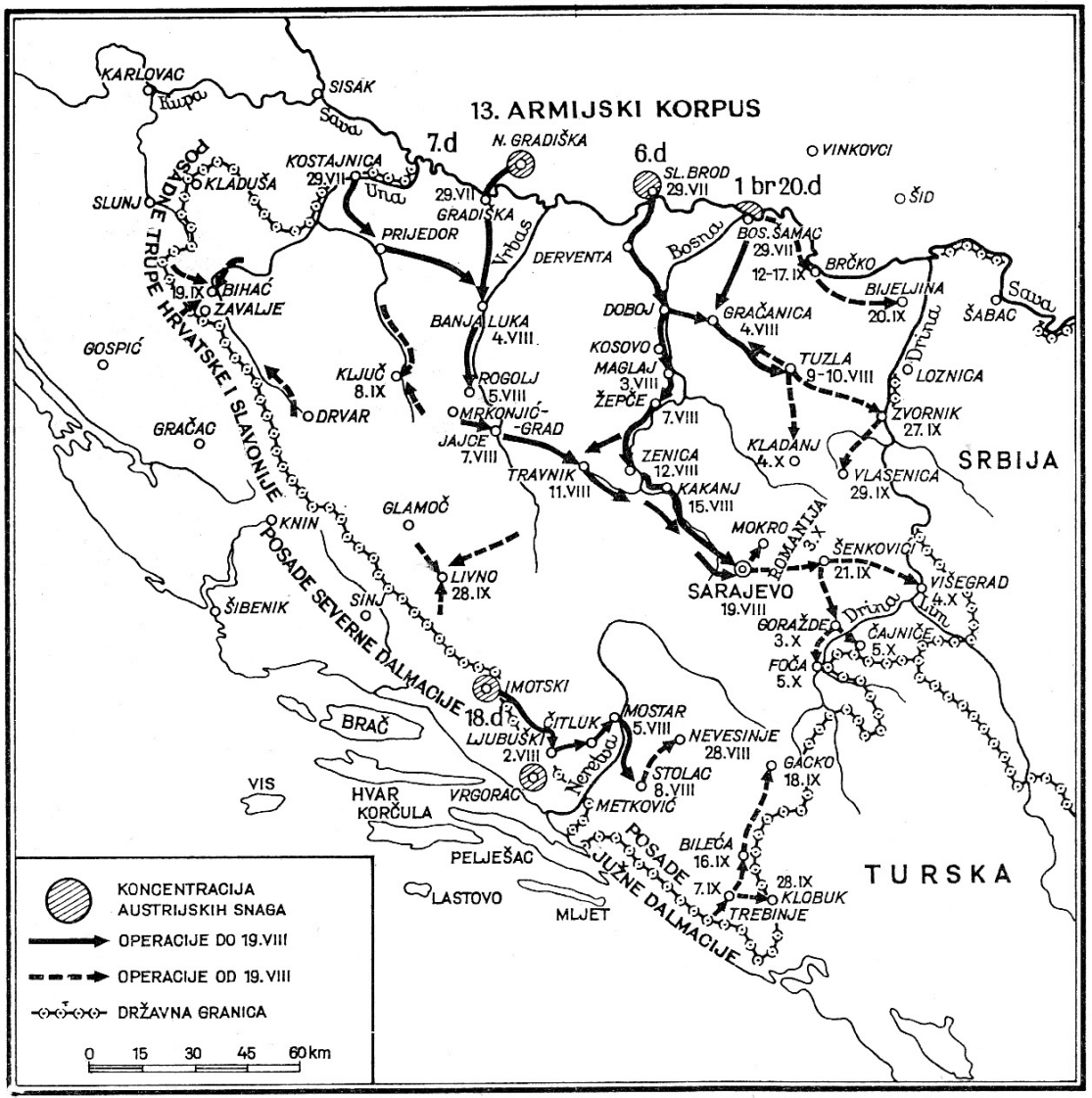

S1. 1. Pravci napada austrougarskih snaga divizijske razine i datumi okupacije pojedinih mjesta u Bosni i Hercegovini. (Izvor: Vojna enciklopedija, sv. 6, str. 361) 
točka Dalmacije ne nalazi se u Hrvatskoj nego u Bosni i Hercegovini. Čak ni najviši vrh Hrvatske na Dinari od 1831 metra nije najviši vrh te planine, nego je to Troglav (1913 m) koji je na bosansko-hercegovačkoj strani. Od rijeke Zrmanje pa do rta Oštro Dalmacija nema taktičku dubinu pa njezina obrana izravno ovisi o obrani njezina zaleđa koje je opet u susjednoj Bosni i Hercegovini. Svaki napad s istoka direktno je ugrožavao dalmatinsku obalu i njezine luke. S druge pak strane, Dalmacija je bila vrlo loše prometno povezana s unutrašnjosti Monarhije što je preko Velebita onemogućavalo kvalitetan promet, a time i brzo prebacivanje vojnih resursa u slučaju krize.

\subsection{Vojni ustroj i razmještaj snaga uoči zaposjedanja}

Odredbe o okupaciji Bosne i Hercegovine iz Berlinskoga sporazuma trebalo je što prije provesti u djelo. Kada politika nije mogla na miran način osigurati prijenos vlasti, morala je nastupiti vojska da silom provede određene političke odluke, odnosno da za političare obavi nasilni i prljavi dio posla. Intenzivne pripreme za mobilizaciju početnih okupacijskih snaga započele su 9. lipnja 1878., a grupiranje snaga završeno je do 6. srpnja. Za vojnoga zapovjednika operacija imenovan je general artiljerije (Feldzugmeister) ${ }^{22}$ Josip barun Filipović, ${ }^{23}$ časnik ličkih korijena, koji je preuzeo zapovjedništvo nad za-

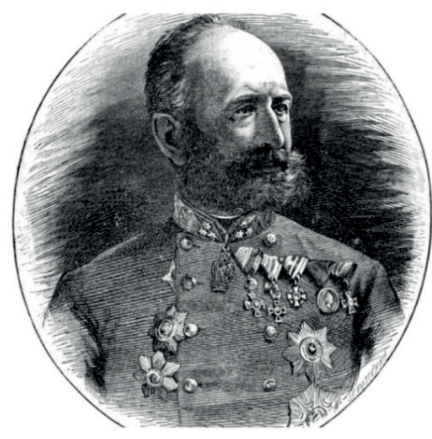

S1. 2. General Josip barun Filipović (Izvor: https://hr.wikipedia. org/wiki/Josip_Filipovi\%C4\%87



Sl. 3. Grob baruna Filipovića u Pragu (snimila dipl. inž. Katarina Kolaković)

22 Ovaj čin odgovara činu današnjeg generala s tri "zvjezdice".

23 General artiljerije (Feldzeugmeister) Josip barun Filipović rođen je u selu Novi kod Gospića 28. travnja 1819., a umro 6. kolovoza 1889. u Pragu. Otac mu je bio graničarski časnik podrijetlom od starobosanskog kršćanskog plemstva. Sina Josipa poslao je u redove svoje l. ličke krajiške pukovnije, u kojoj stječe čin kadeta. 


\section{grebačkim XIII. korpusom (zborom) ${ }^{24}$ koji je operativno rukovodio cjelokupnim operacijama.}

Dvije godine nakon toga poslan je u pionirsku zbornu školu u Tullnu na Dunavu, gdje je promaknut u čin poručnika. Godine 1848. za vrijeme revolucionarnih događaja u Monarhiji upoznaje ga hrvatski ban Jelačić, koji mu daje priliku da iskaže svoje vojničke sposobnosti u borbi protiv Mađara. Prilikom zauzeća Beča (31. listopada 1848.) Filipović je ranjen, a zatim se istaknuo u bojevima kod Schwechata, Parendorfa, Altenburga i Moora, te je unaprijeđen u čin bojnika (majora), i službuje u 5. graničarskoj varaždinsko-križevačkoj pukovniji.

Godine 1849. sudjeluje u borbama kod Tetenya, te u bitkama kod Kapolne, Isaszega, Hegyesa i dr., zbog čega je odlikovan Križem za zasluge i Viteškim križem Leopoldova reda. Godine 1851. promaknut je u čin potpukovnika (njem. Oberstlieutenants) te postaje pobočnik bana Jelačića. Početkom 1853. promaknut je u pukovnika (njem. Oberst) i stupa na dužnost zapovjednika 5. varaždinsko-križevačke krajiške pješačke pukovnije. Zbog iznimnih vojničkih zasluga godine 1859. unaprijeđen je u general bojnika i zapovjednika jedne brigade VIII. korpusa (zbora), koja se istaknula u borbama kod Torre di Beretti i Solferina. Zbog uspješnih borbi Filipović je odlikovan Redom željezne krune II. reda i barunskim naslovom. Početkom šezdesetih godina XIX. stoljeća uključuje se u politiku kao carski povjerenik srpskog narodnog kongresa u Novom Sadu i postaje predsjednik sinode pravoslavnoga metropolita, zbog čega je odlikovan Viteškim križem reda sv. Stjepana.

U vrijeme prusko-austrijskog rata iz 1866. istaknuo se u bitci kod Koniggratza i u bojevima kod Kukusa i Požuna (današnje Bratislave), te postaje podmaršal. Nakon toga bio je više godina zapovjednik 8. pješačke divizije u Beču i Insbrucku. Godine 1874. postaje general artiljerije (Feldzugmeister) sa službom u Brnu, a nakon toga odlazi u Prag na dužnost vojnog zapovjednika za Češku. Tu je dobio zapovijed za preuzimanje zapovjedništva nad zagrebačkim XIII. korpusom (zborom) i zadaću okupacije Bosne i Hercegovine. Nakon završetka vojnih operacija Filipović će kratko ostati na dužnosti civilno-vojnoga poglavara Bosne i Hercegovine. Nasljeđuje ga vojvoda Wilhelm Nikolaus od Württemberga, njemački aristokrat, a Josip će se vratiti u Prag, gdje će mu biti dodijeljen Zapovjedni križ vojnoga reda Marije Terezije. Kraće je vrijeme bio zapovjednik 2. korpusa u Beču, da bi se ubrzo vratio u Prag, gdje će sve do svoje smrti ostati njegovim vojnim zapovjednikom. Dobio je mnoga odličja poput Velekriža pape Grgura, Pruski red crvenoga orla, Vitez ruskoga reda bijeloga orla, osmanski medžidski red 1. razreda, Velekriž belgijskoga Leopoldskog reda, talijanski Red sv. Mavre i Lazara, francusko odličje Legije časti i Red rumunjske zvijezde. Josip je bio oženjen s baronesom Leontinom Joëlson, s kojom je imao dvije kćeri: Gizelu i Paulu. Izvor: Militär-Schematismus des österreichischen Kaiserthums. Wien, 1834-1848, 1855-1856, 1863; Kais. Königliche Militär Schematismus für 1877-1878. Wien, 1878-1879; M. Mandić, Povijest okupacije Bosne i Hercegovine 1878, str. 33-34.

24 Armijski korpus (corps d'armée), najviša operativna postrojba u kopnenoj vojsci, sastavljena je od 2 do 3 pješačke divizije. Za vrijeme NDH koristio se naziv "zbor". 
Uoči napada u Hrvatskoj i Slavoniji zagrebačka 36. pješačka divizi$\mathrm{ja}^{25}$ ojačala je svoje krajiške snage koje su do tada bile razmještene u obrani Vojne krajine (Militärgrenze) i tu je ostala do druge faze napada, odnosno, do mobilizacije i pristizanja ojačanja tijekom kolovoza. Računajući da će raznim obećanjima uspjeti oslabiti otpor naroda u Bosni i Hercegovini, austrougarsko vrhovno zapovjedništvo planiralo je u početku manje snage, uglavnom iz sastava zagrebačkog XIII. korpusa uz manja ojačanja iz okolnih korpusa. U početnom sastavu snaga bile su mobilizirane 6., 7., i 20. pješačka divizija za napad na Bosnu sa sjevera, prvenstveno dolinama rijeka Vrbasa i Bosne, čime bi se stvorila manja područja za kasnije operativno čišćenje prostora. U Dalmaciji je 18. pješačka divizija razmještena za napad na Hercegovinu. Važno je napomenuti da je zapovjednik 18. pješačke divizije bio još jedan Hrvat, podmaršal (Feldmarschalleutnant) Stjepan barun Jovanović, ${ }^{26}$ koji je zapovijedao desnim napadnim krilom iz Dalmacije.

25 Pješačka divizija imala je oko 18.000 ljudi, koji su bili razdijeljeni u dvije brigade koje su opet imale 2-3 pukovnije (regimente, puka).

26 Podmaršal Stjepan (Stevan) barun Jovanović rođen je u Pazarištu (kotar Otočac u Lici) 5. siječnja 1828., a umro je u Zadru 8. prosinca 1885. Temeljnu vojnu naobrazbu stekao je u Grazu, te je godine 1845. postao kadet. Sudjeluje 1848. i 1849. u ratu s Italijom. Nakon toga je upućen u vojno-diplomatsku misiju u Kotor, zatim u glavni stan Omer-paše u Spužu i crnogorskog kneza Danila. Nakon toga zauzimao je važan položaj kod generalnog zapovjedništva u Zadru, da bi zatim bio premješten u Galiciju (1856.). U vremenu od 1856. do 1858. boravi povremeno i u Hrvatskoj i Dalmaciji, te je uključen u kartiranje dijelova Ugarske, da bi u ljeto 1858. bio imenovan austrougarskim zastupnikom u internacionalnom povjerenstvu za definiranje tursko-crnogorske granice.

Za vrijeme rata 1859. Jovanović je u sastavu brigade generala Rodića u južnoj Dalmaciji i za zasluge što ih je tamo stekao, poglavito u Boki kotorskoj, dobiva Red željezne krune III. reda. Tijekom 1859. unaprijeđen je u čin bojnika (majora) za vrijeme službe u Generalnom zapovjedništvu u Zadru. Nakon toga imenovan je predsjednikom povjerenstva za uređenje granice.

Jedno vrijeme bio je ađutant hrvatskoga bana podmaršala baruna Šokčevića, a u proljeće 1861. zastupa Austro-Ugarsku u internacionalnom povjerenstvu u Mostaru, kada je unaprijeđen u čin potpukovnika. Pritom mu je povjerena uprava generalnoga konzula u Bosni. Na kraju 1865. godine unaprijeđen je $\mathrm{u}$ pukovnika, te se u tome činu istaknuo tijekom talijanskoga rata iz godine 1866. kod Mantove i sela Portinarolo. Zbog ranjavanja i zasluge dobio je vojnički križ.

U vrijeme ustanka u Boki kotorskoj godine 1869. opet je ranjen zbog čega dobiva Viteški križ Leopoldova reda, i nakon toga postaje zapovjednik brigade u 
Ukupno je bilo operativno angažirano 56,5 pješačkih bojni, oko 14 eskadrona konjice, 112 topova i 12 satnija inženjerije (sapera i pontonira), sveukupno oko 82.000 pripadnika uključujući i postojeće granične snage. ${ }^{27}$

\subsection{Operacije planiranih snaga}

Nasilna promjena granica i vlasti često uzrokuje kaos, osjećaj očaja, gubitak ponosa i časti podređenih naroda. One su stvorile nesigurnost kod većine građana Bosne i Hercegovine, osobito kod musli-

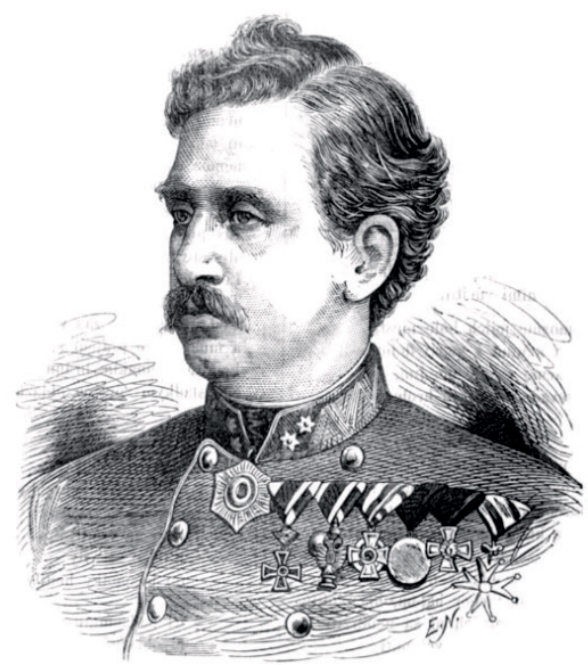

Sl. 4. Podmaršal Stjepan Jovanović (Izvor: wikipedia.org/wiki/Stjepan_ Jovanović\#/media/File:Orol_1878-11_ Štefan_Jovanovič.png)



Sl. 5. Grob podmaršala Jovanovića na vojnom groblju u Dubrovniku (Snimio dr. sc. Filip Hameršak)

južnoj Dalmaciji u svibnju 1870. gdje je prinudni upravitelj nad Kotorom. Sljedeće godine (1871.) promaknut je u generala. Tijekom posjeta kralja Dalmaciji u proljeće 1875., podijelio mu je naslov baruna. U jesen 1876. unaprijeđen je u podmaršala, a u lipnju 1877. preuzeo je zapovjedništvo 18. pješačke divizije u Splitu, s kojom će stupiti na hercegovačko tlo u ljeto 1878. Izvor: M. MANDIĆ, Povijest okupacije Bosne i Hercegovine 1878, str. 34; TAdo Oršolić, Sudjelovanje dalmatinskih postrojbi u zaposjedanju Bosne i Hercegovine 1878., Radovi Zavoda za povijesne znanosti HAZU u Zadru, 42, Zadar, 2000., str. 290.

27 M. Mandić, Povijest okupacije Bosne i Hercegovine 1878, str. 33; Vojna enciklopedija, sv. 6, str. 360-361. 
manskoga stanovništva. Vijest o pokretu austrougarskih snaga izazvala je masovan ustanak stanovništva, uglavnom muslimanskoga i nešto manje pravoslavnoga, koje je zahtijevalo autonomiju predviđenu poništenim Sanstefanskim ugovorom. U Sarajevu su izbili sukobi između pristaša otporu okupaciji, predvođeni Hafizom hadži Lojom, i centralne turske vlasti, što se uskoro proširilo na većinu ostalog prostora. Oni su 28. srpnja organizirali neformalnu vladu koja je preuzela gotovo svu vlast i pozvala narod na ustanak te proglasila mobilizaciju. Ubrzo su njihove vojne snage dosegle broj od oko 13.800 vojnika iz sastava turskih postrojbi i oko 79.200 dragovoljaca-ustanika (ustaša) koji su raspolagali sa 75 topova, ili ukupno oko 93.000 boraca. Za zapovjednika tih snaga imenovan je Smailbeg Selmanović Taslidžak. Zbog rascjepkanosti snaga nije uspostavljen jedinstven sustav vođenja i zapovijedanja. ${ }^{28}$ Tijekom gotovo tri mjeseca borbi ove će operacije biti veoma brutalne s obje zaraćene strane. Zabilježeni su brojni nehumani događaji izvan ratnog prava, osobito nad zarobljenicima.

Iako je postignut sporazum o okupaciji između Austro-Ugarske i Osmanskoga Carstva, čini se da je Turska igrala tzv. "dvostruku igru". Naime, činjenica je da su se turske postrojbe, stacionirane u $\mathrm{BiH}$, trebale povući s toga područja, ali se ipak velik broj turskih vojnika ostao boriti zajedno s domaćim snagama. Turska je vojska za sobom ostavila gotovo sav postojeći oružani arsenal te time omogućila da ustaničke snage pruže maksimalan otpor austrougarskim postrojbama i nanesu im velike i nepredvidive gubitke. ${ }^{29}$

General Filipović odredio je da se granica prijeđe na šest težišnih mjesta: kod Šamca, Broda, Gradiške, Kostajnice, Vrgorca i Imotskog. $\mathrm{U}$ tako reljefno nepovoljnom planinskom području, kao što je Bosna i Hercegovina, Austro-Ugarska u početku nije mogla razviti veće snage zbog loših prometnica. ${ }^{30}$ Napad je počeo 29. srpnja kada su austrougarske snage bez značajnijeg otpora prešle rijeke Savu i Unu. Prvi jači otpor i veće borbe za 6. pješačku diviziju započele su 6. kolovoza kod Maglaja i Žepča. Velike poteškoće u pokretu snaga stvarale

28 Vojna enciklopedija, sv. 6, str. 360; M. Mandić, Povijest okupacije Bosne i Hercegovine 1878, str. 100.

29 Rade Petrović, Pokret otpora austrougarske okupacije 1878. godine u Bosni i Hercegovini, Otpor austrougarskoj okupaciji 1878. godine u Bosni i Hercegovini, ANU BiH, Sarajevo, 1979., str. 48-51.

30 M. Mandić, Povijest okupacije Bosne i Hercegovine 1878, str. 37. 
su česte oluje i obilne padaline koje su uništavale ionako loše prometnice. Poslije teških borbi austrougarske su snage, nakon pristiglih ojačanja, na te pravce primorale ustanike na povlačenje prema Zenici. Ojačanja su sačinjavale pukovnije 1. i 36. pješačke divizije.

Tijekom 31. srpnja 7. pješačka divizija ulazi u Banju Luku i nakon toga kreće prema Mrkonjić Gradu. Na tom pravcu događaju se jače borbe kod Jajca da bi tijekom 11. kolovoza zauzela Travnik i tu došla u kontakt sa snagama 6 . pješačke divizije iz pravca Žepča te zajednički nastavile napad prema Sarajevu. Važno je napomenuti da je u bojevima kod Jajca i Mrkonjić Grada 3. kolovoza sudjelovala zagrebačka 53. pješačka pukovnija pod zapovjedništvom brigadira Hostineka. ${ }^{31}$ Nakon odlaska 7. pješačke divizije prema Mrkonjić Gradu početkom kolovoza u zapadnoj Bosni nastupila je anarhija i bezvlašće. Tijekom 14. kolovoza pod vodstvom Hasan-bega Čekića ustanici su napali Banju Luku. U obrani grada naći će se jedna skupina otočačke 79. pješačke pukovnije i četiri satnije 22. pješačke pukovnije iz Trsta koje su uz krajnje napore uspjele spriječiti gubitak grada. U pomoć su poslani dijelovi 12. topničke bitnice i dvije satnije bjelovarske 16 . pješačke pukovnije koje su uspjele prisiliti ustanike na povlačenje u okolna brda. Gubitci austrougarskih snaga bili su veliki: 46 poginulih, 117 ranjenih i osam zarobljenih. "Jelačićevci" će imati jednog poginulog i četiri ranjena pripadnika. ${ }^{32}$ Učestale su borbe i diverzije u pozadini napadnih kolona zbog čega je bilo potrebno izdvojiti značajne snage za zaštitu osvojenih područja, komunikacija i važnijih objekata.

Ipak, najteže borbe imala je tijekom 9. i 10. kolovoza lijeva kolona sastavljena od snaga 20. pješačke divizije kod Tuzle gdje se branilo oko 6.000 ustanika. Zbog veoma velikih gubitaka divizija se morala povući najprije prema Gračanici a kasnije prema Doboju (11.-15. kolovoza). U ovim borbama sudjeluju tri bojne ličke 79. pješačke pukovnije o čemu će biti više riječi u nastavku teksta, te dijelovi 70. pješačke pukovnije iz Petrovaradina kod Šamca tijekom 15. kolovoza. ${ }^{33}$

Snage 18. pješačke divizije, koje su napadale iz Dalmacije prema Hercegovini, imale su također mnogo problema na svojim pravcima na-

31 Isto, str. 44, 47.

32 Isto, str. 55-56; Die Occupation Bosniens und der Herzegovina durch K.K. Truppen im Jahre 1878, nach autentischen Quellen, Prilog 12.

33 M. Mandić, Povijest okupacije Bosne i Hercegovine 1878, str. 50-51. 
pada. Pri ulasku podmaršala Jovanovića u Mostar izbila je krvava buna tijekom 31. srpnja u kojoj su stradali brojni turski vojni i civilni dužnosnici koji su se protivili otporu okupaciji. Grad je bio veoma devastiran, a ustanici su razgrabili naoružanje i time bitno otežali ulaz austrougarskih snaga u Mostar. Nakon intenzivnih borbi tijekom 5. kolovoza okupacijske snage ušle su u Mostar uz prethodne borbe kod Čitluka, prisilivši ustaničke snage na povlačenje prema području Foče, Gacka, Bileće i Trebinja. Dio tih snaga naknadno je sudjelovao u opsadi Stoca. ${ }^{34}$ Stolac je pao tijekom 11. kolovoza. Prilikom napada na Ljubinje kod mjesta Ravnice napadnute su austrougarske snage koje su se zbog toga morale povući u Stolac koji se našao u opsadi. Zbog velikih gubitaka podmaršal Jovanović primoran je povući posadu iz Stoca. Nakon krvavih borbi i pobjede kod Crnića i Pašića hana tijekom 19.-21. kolovoza ponovo je zauzet Stolac i time im je omogućen nastavak operacija. U tim se borbama posebno istaknula skupina don Ivana Musića. Nakon teških borbi okupirano je područje Trebinja (7. rujna), Bileća i Gacko do 18. rujna, a Klobuk je pao 28. rujna. Time je podmaršal Jovanović zauzeo sve planirane prostore u Hercegovini. ${ }^{35}$

Sagledavajući vrlo složeno stanje na ostalim pravcima napada general Filipović zadržao je 20. pješačku diviziju kod Doboja, 7. diviziju na komunikaciji Banja Luka - Travnik, a s ostalim snagama od oko 13.000 vojnika i 52 topa produžio je pokret preko Kaknja prema Sarajevu. Uz prethodne borbe kod hana Ovčiluka i Bilalevca 16. kolovoza, Kaknja 15. i 16. kolovoza, Visokog 17. kolovoza, izbio je do Sarajeva tijekom 19. kolovoza koje je pod zapovjedništvom Muhameda Hadžijamakovića branilo oko pet-šest tisuća ustanika s 20 topova. U oštrim borbama austrougarske snage ubrzo su zauzele grad uz vlastiti gubitak od 373 ljudi. ${ }^{36} \mathrm{U}$ međuvremenu napadne snage ojačane su s 1., 4 . i 36. pješačkom divizijom na glavnim pravcima napada i 20. pješačkom brigadom u Hercegovini kako bi što prije provele okupaciju. ${ }^{37}$

Zbog pojačanih aktivnosti ustanika u Bosanskoj krajini i bojazni od dolaska albanskih dobrovoljaca austrougarsko vrhovno zapovjedniš-

34 O tome detaljnije u: T. Oršolić, Sudjelovanje dalmatinskih postrojbi u zaposjedanju Bosne i Hercegovine 1878., str. 300 i dalje.

35 M. Mandić, Povijest okupacije Bosne i Hercegovine 1878, str. 66-70.

36 Die Occupation Bosniens und der Herzegovina durch K.K. Truppen im Jahre 1878, nach autentischen Quellen, Prilog 12.

37 M. Mandić, Povijest okupacije Bosne i Hercegovine 1878, str. 46. 
tvo tijekom 21. kolovoza značajnije ojačava napadne snage i mobilizira nove poput zapovjedništava korpusa (zbora): ${ }^{38}$ III. (Graz), IV. (Budimpešta) i V. (Bratislava) i od tih snaga i postojećih iz zagrebačkoga XIII. korpusa ustrojava 2. armiju (vojsku). ${ }^{39}$ Armijom je zapovijedao general Filipović a imala je oko 150.000 ljudi i 276 topova. ${ }^{40}$

Novim planom operacije bilo je određeno da IV. korpus i dio snaga iz III. korpusa pokriju sjeveroistočnu, dvije divizije jugoistočnu, a zagrebački XIII. korpus sjeverozapadnu Bosnu. Armijska pričuva, koju je sačinjavao V. korpus, razmještena je u širem prostoru Nove Gradiške. Ovako ojačane snage stvorile su nadmoć nad ustanicima koji većim dijelom odustaju od daljnjih borbi. Jedino je zabilježen ozbiljniji otpor u vremenu od 12. do 17. rujna kod Brčkog i u Bosanskoj krajini, osobito prilikom osvajanja Ključa (24. kolovoza do 8. rujna) kojeg je branilo oko 1500 ustanika. U tim je borbama sudjelovala jedna bojna zagrebačke 53. pješačke pukovnije, a osječka 78. i petrovaradinska 70. pješačka pukovnija sudjeluju u borbama kod Doboja tijekom 23.-26. kolovoza. U ovim aktivnostima izbačeno je iz stroja oko 300 austrougarskih vojnika. ${ }^{41} \mathrm{U}$ borbama kod hana Pirkovca i Milinog sela tijekom 17.-19. rujna sudjeluje petrovaradinska 70. pješačka pukovnija. ${ }^{42}$

Treba napomenuti da je Tuzla pala tek 22. rujna što govori o težini borbi na tom području. Istočna Bosna, uključujući i Podrinje, osvojena je krajem rujna i početkom listopada (Višegrad, Čajniče i Goražde). Livno je palo nakon pada Bihaća 28. rujna. Manje borbe nastavljene su do 20. listopada. Time je završila okupacija Bosne i Hercegovine. Nakon okupacije prišlo se sanaciji komunikacija i popravku vitalnih objekata koji su u vojnim djelovanjima oštećeni. Nova vlast osudila je vođe ustanka, većinu njih na smrt. ${ }^{43}$

38 U sastavu ovoga korpusa bile su 1., 4. i 20. pješačka divizija.

39 Armija (njem. Armee; tal. armata; engl. army; franc. armée) najviša je operativno-strategijska ustrojstvena cjelina kopnene vojske koja djeluje na posebnom operacijskom pravcu ili na zasebnom bojištu. Jedna armija u pravilu sastojala se od 2-3 korpusa (zbora), a rjeđe od samih divizija.

40 Vojna enciklopedija, sv. 6, str. 361; Die Occupation Bosniens und der Herzegovina durch K.K. Truppen im Jahre 1878, nach autentischen Quellen, Prilog 9.

41 M. Mandić, Povijest okupacije Bosne i Hercegovine 1878, str. 85.

42 Isto, str. 76-77; Vojna enciklopedija, sv. 6, str. 361.

43 M. Mandić, Povijest okupacije Bosne i Hercegovine 1878, str. 73; JAnko KoHARIć - FERdo Šišić, Zapamćenja fra Grge Martića, Trpinac, Zagreb, 1906., str. 108. 


\section{Ličani u okupaciji Bosne i Hercegovine}

\subsection{Djelovanja 79. pješačke pukovnije u sastavu 6. i 20. pje- šačke divizije u Sjevernoj Bosni}

Godine 1873. ustrojena je 79. ugarska (hrvatska) pješačka pukovnija, mobilizacijski je pokrivala šire područje Like i dio Korduna i s toga se područja popunjavala. U godini 1878. pukovnijom je zapovijedao pukovnik (Oberst) Julije Kristijanović, a pričuvnim dijelom (četvrta i peta bojna) potpukovnik (Oberstlieutenants) Aleksandar Kokotović. Prve tri bojne i zapovjedništvo pukovnije bile su mirnodopski stacionirane u Grazu (Austrija), a pričuvne IV. i V. bojna su u stanju mobilizacijske pripravnosti na širem području Like. Pričuvno zapovjedništvo bilo je u Otočcu. ${ }^{44}$

U pukovniji su osim navedenih časnika bili još potpukovnik Karlo Halavanja pl. Radojčić, bojnici (majori) Sebastijan Prebeg i Karlo Balaško; satnici (Hauptleute 1. i 2. Classe): Josip pl. Novaković od Đuraboja, Ivan Fudurić, Petar Petričić, Eduard Piškur, Đuro Halavanja pl. Radoičić, Paul Lukić, Simon Rabatić, Ignac Šumonja, barun Marko pl. Jurković, Karl Čičerić; satnici (Hauptleute 2. Classe): Samuel Vitas, Ivan Kasumović, Teofil Halavanja pl. Radoičić, barun Emerih Rukavina pl. Vidovgrad, Emerih Karlić, Ludvig Herceg, Damjan Gruičić, Petar Kovačević, Ivan Vukojević, Nikola Sedlar, Luka Marjanović, Luka Medić, Đuro Trbuhović, Živko Ranisavljević: natporučnici (Oberlieutenants): Đuro Đurić, Andrija Demić, Đuro Bekić, Nikola Horvat, Franjo Perčević, Paul Marinović, Danijel Branković, Stjepan Latas, Nikola Pekeč, Petar Krajnović, Đuro Pocrnić, Josip Milković, Marko Velebit, Franjo Bistrić, Raimund Dujić, Mihael Grozdanić, Đuro Turkalj, Danijel Kovačević, Emanuel Radulović, Adam Smolčić, Stjepan Pjevac, Ivan Čanić, Stjepan Španić, Ivan Vuletić, Stanislav Gazdović, Ivan Jerbić; poručnici (Lieutenants): Josip Kalaš, Ludvig Holik, Ilija Kukić, Franjo Rukavina, Mihael Žegarac, Franjo Malvić, Karl Matanović, Ivan Borić, Raimund Pešut, Ivan Rončević, Alojz Pribanić, Matija Kulaš, Alojz Prebeg, Pavao Brmbolić, Richard Rubeš, Josip Rivnač, Eduard Blašković, Ivan Sertić, Ludvig Toplak, Milovan Gavrančić, Karl Fröhlich, Konstantin Mandić, Ivan Valentić, Petar Babić, Đuro Miljuš, Emanuel Pribić, Karl Matasić, Ambros

44 Kais. Königliche Militär Schematismus für 1878, Aus der k.k. Hof-und Staatsdruckerei, Wien, 1877, str. 342. 


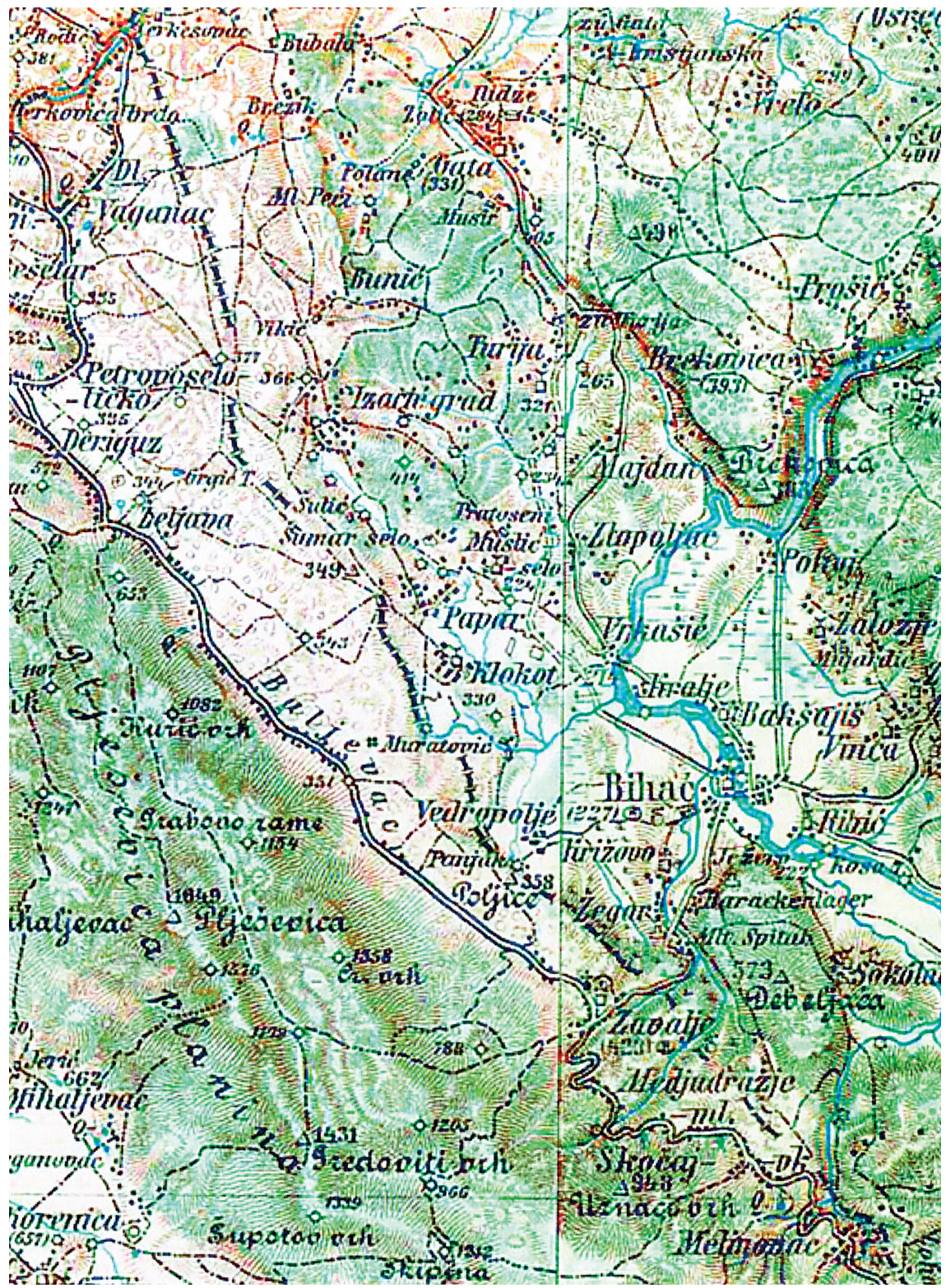

S1. 6. Prostor šireg područja Bihaća, mjesta borbi tijekom okupacije Bihaća. Izvor: http://lazarus.elte.hu/hun/digkonyv/topo/3felmeres.htm, Index sheet of the general map of Central Europe (dio) (1:200 000). 
Ćutić, Mihael Uzelac, Julije Bartaković, Danijel Ćutić, kadeti: Ivan Bićanić, Ivan Rajković, Prokopije Dmitrašinović, Gabrijel Šašić, Josip Matijević, Nikola Španičić i Danijel Vladetić. ${ }^{45}$

U okupaciji Bosne i Hercegovine 79. pješačka pukovnija djelovala je u dvije skupine: prve tri bojne (bataljuna) sudjeluju u sastavu 6. pješačke divizije na pravcu Slavonski Brod - Doboj, a pričuvne - četvrta i peta pričuvna bojna - na širem području Bihaća.

Pukovnija je u dva dijela napustila Graz tijekom 13. i 14. srpnja i iskrcala se u Osijeku. Nakon toga upućena je u Slavonski Brod i razmještena u Stupniku, Oriovcu i Radovanju. Tu se spojila s još pet graničnih pukovnija koje su tamo bile stacionirane u obrani granice. Početni moral vojnika bio je dobar. Ove bojne ulaze u sastav 2. brdske brigade/6. pješačke divizije. Divizijom je zapovijedao podmaršal Carl pl. Tegethoff, a brigadom pukovnik (Oberst) G. Lemajić. U brigadi su još 9. lovačka bojna iz Klagenfurta i četvrta bitnica (baterija) 1. pukovnije brdskog topništva, da bi ubrzo nakon toga ove snage ušle u sastav 20. pješačke divizije. ${ }^{46}$ Brigada je nakon toga zajedno s 39 . pješačkom brigadom $^{47}$ krenula prema Maglaju i Vranduku. Tu je pukovnija dobila tešku zadaću obrane i pokrivanja širokog prostora u neprijateljskom okruženju uza stalna bojna djelovanja ustaničkih grupa.

Istovremeno se u sjeveroistočnoj Bosni ustanak počeo masovno širiti zbog čega je bilo otežano napredovanje 20. pješačke divizije u proboju prema Tuzli i Zvorniku. Naime, 20. pješačka divizija došla je u iznimno tešku krizu kada je kod hana Pirkovca (8. kolovoza) i na prilazima Tuzli (9. i 10. kolovoza) napadnuta premoćnim ustaničkim snagama koje nije mogla neutralizirati. Zbog toga se morala povući prema Gračanici gdje je trebala prihvatiti pojačanja i nakon toga opet krenuti u protunapad. Stigavši u Gračanicu situacija se nije poboljšala: ljudstvo je napadnuto i divizija je bila prisiljena nastaviti povlačenje prema Doboju. Dolaskom u Doboj 16. kolovoza diviziju je opet napala masa ustanika sa snažnom uporabom topništva. Ipak,

45 Kais. Königliche Militär Schematismus für 1879, Aus der k.k. Hof-und Staatsdruckerei, Wien, 1878, str. 394-395.

46 Die Occupation Bosniens und der Herzegovina durch K.K. Truppen im Jahre 1878, nach autentischen Quellen, Prilog 3.

47 Zapovjednik brigade general E. Kaiffel. U brigadi su zagrebačka 31. lovačka bojna, 38. linijska pješačka pukovnija iz Vinkovaca, 6. pričuvna pješačka pukovnija iz Novog Sada. Izvor: Die Occupation Bosniens und der Herzegovina durch K.K. Truppen im Jahre 1878, nach autentischen Quellen, Prilog 5. 
uz velike gubitke divizija se uspjela održati na svojim obrambenim položajima. Tu su ustanici planirali okružiti diviziju i uništiti je što bi dovelo do prekida prometa dolinom rijeke Bosne prema Sarajevu i imalo nesagledive posljedice za snage koje su već napredovale prema Sarajevu. Ali probojem 7. pješačke divizije od Banje Luke prema Travniku (11. kolovoza) i dalje prema Zenici, te spajanjem sa snagama 6. pješačke divizije kod Travnika rasterećene su snage 20. pješačke divizije. Borbe kod Doboja potrajat će sve do 5. rujna kada su pristigla ojačanja sposobna uništiti ustanike. Nakon toga nastavljene su teške borbe uz cestu prema Maglaju čime je ova vrlo važna prometnica otvorena za sav promet.

Zbog navedenih problema oko djelovanja 20. pješačke divizije tijekom 13. kolovoza dolazi u Doboj zapovjedništvo druge bojne 79. pješačke pukovnije. Tu dobiva zapovijed od 20. pješačke divizije da osigura prijelaz rijeke Bosne za prihvat snaga koje se povlače iz Tuzle prema Doboju. Nakon prihvata snaga ova bojna pod zapovjedništvom satnika Čićerića upućena je prema Tešnju zajedno sa skupinom Husara. Kod Tešnja upadaju u neprijateljsku vatru i tu vode teške borbe. ${ }^{48}$

\subsection{Pripreme za okupaciju Bihaća}

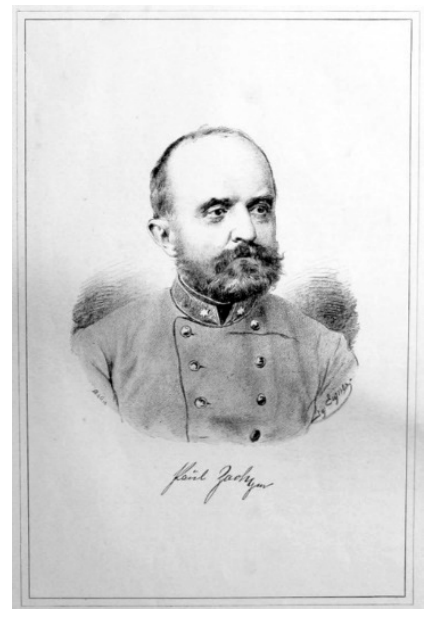

S1. 7. General Paul pl. Zach

(Izvor: https://de.wikipedia.org/wiki/Paul_Ritter_ von_Zach\#/media/Datei:Paul_Ritter_von_Zach.jpg)

48 Carl Schmarda, Kurzgefasste Geschichte des k.u.k. Otočaner Infanterie-Regiment Graf Jellačić Nr. 79 und seiner Stammregimenter. Im Auftrage des herrn K.und K. Obersten und Regiments-Commandanten Heinrich Hennevogl von Ebenburg. Tisak: von C. Albrecht (Jos. Wittasek), Zagreb, 1898., str. 57; M. Mandić, Povijest okupacije Bosne i Hercegovine 1878, str. 78. 
Zbog nedostatka operativnih snaga i povećanja aktivnosti na ostalim bojištima, okupacija zapadne Bosne planirana je kao posljednja faza operacija. Napadom na Bihać i Ključ htjelo se osloboditi zapadnu Bosnu i time olakšati stanje postrojbi na širem operativnom području, osobito oko Livna, gdje su se još uvijek nalazili brojni ustanici i turski vojnici. Zasigurno je bilo dilema da li započeti s operacijama prije nego dođu potrebna pojačanja ili s trenutačno raspoloživim snagama. Što je bio povod da u napad krene samo jedna brigada na tako složenom prostoru i po vrlo nepovoljnim vremenskim (maglovitim) uvjetima teško je reći jer se moglo pretpostaviti da je uspjeh operacija vrlo upitan. Bihać i okolicu branilo je između 8000 do 9000 ustanika, a po nekim izvorima i do 15.000, što je bilo daleko više od napadnih snaga. Računa se da je u Krajini i zapadnoj Bosni bilo stacionirano oko 41.000 ustanika i turskih vojnika. ${ }^{49}$ Nositelj napadnih operacija na Bihać bila je 72. pješačka brigada ${ }^{50}$ iz 36 . pješačke divizije ${ }^{51}$ kojom je zapovijedao general bojnik Paul pl. Zach, a glavnostožerni časnik bio je natporučnik Aleksandar Milenković. Borbe kod Bihaća tijekom 7. rujna 1878. ubrajaju se u najkrvavije u čitavoj okupaciji Bosne i Hercegovine.

Pripreme 79. pješačke pukovnije iz Otočca za ovu operaciju započele su tijekom 12. srpnja kada je mobilizirana peta bojna 79. pukovnije i pričuvno zapovjedništvo kojim je zapovijedao potpukovnik Aleksandar Kokotović. Zapovjednik četvrte bojne bio je satnik Karlo Balaško, a pete satnik Marko pl. Jurković. Nakon priprema i uvježbavanja snaga u vojarni u Otočcu tijekom 13. kolovoza krenulo je prema bojištu oko 500 ljudi, koji su stigli 15. kolovoza na područje Ličkog Petrovog Sela i Željave i tu su bili u pripravnosti za daljnje

49 M. Mandić, Povijest okupacije Bosne i Hercegovine 1878, str. 86, 100; C. ScHMARDA, Kurzgefasste Geschichte des k.u.k. Otočaner Infanterie-Regiment Graf Jellačić Nr. 79, str. 58.

50 U sastavu brigade bila je: 23. linijska pješačka pukovnija iz Sombora (Vojvodina), dvije bojne 79. pričuvne pješačke pukovnije, dvije bojne 53. pričuvne pješačke pukovnije iz Zagreba, hrvatske 87. i 88. domobranska bojna iz Zagreba, 76. pričuvna pješačka pukovnija iz Soprona (Ugarska) i 12. lovačka bojna iz Kolina (Češka), Brigadnu pričuvu sačinjavale su 1. lovačka bojna iz Terezina (Češka), jedna satnija Landwehra i teška bitnica 3/12. topničke pukovnije iz Ljubljane. Izvor: Die Occupation Bosniens und der Herzegovina durch K.K. Truppen im Jahre 1878, nach autentischen Quellen, Prilog 5.

51 U sastavu divizije bile su 2. i 72. pješačka brigada. Izvor: Die Occupation Bosniens und der Herzegovina durch K.K. Truppen im Jahre 1878, nach autentischen Quellen, Prilog 5. 
zadaće. Ubrzo tamo stiže i ostatak snaga. Tu će nastaviti s pripremama za bojna djelovanja i opremanjem logističkim potrepštinama. ${ }^{52}$ Tijekom 13. kolovoza u Zavalje stiže zapovjedništvo 72. pješačke brigade. Idućeg dana general Zach upućuje zapovjedniku Bihaća poziv na pregovore. Istog dana došlo je izaslanstvo i pregovori su počeli na sjenovitu trgu pod Raštelom. ${ }^{53} \mathrm{Na}$ čelu izaslanstva bio je Husein efendija Karabegović, tajnik zadnjega turskog paše koji je protjeran iz bihaćkog sandžaka. Pregovori nisu uspjeli i Zach nastavlja s planiranjem napada bez obzira što su njegove snage bile inferiornije u odnosu na obranu. Dok su se zapovjednici pripremali za bojeve, vojnici 23. pukovnije iz Sombora (Vojvodina) plesali su mađarske čardaše ili srpska kola, a Ličani iz 79. pukovnije pjevali su sjetne pjesme. ${ }^{54}$

\subsection{Borbe tijekom 7. rujna}

Tijekom 6. rujna general pl. Zach donosi konačnu zapovijed o napadu na Bihać. Oko tog utvrđenog mjesta nalazile su se značajnije ustaničke snage pod vodstvom već spomenutoga Husein-bega Karabegovića koje su zbog svoje brojnosti i snage direktno ugrožavale granicu monarhije. Računa se da su na prednjim položajima oko Bihaća bile razmještene značajne snage ustanika nasuprot Zachove brigade, a ostatak je bio razmješten po dubini prostora i bio je mobilan za djelovanje prema razvoju situacije na širem operativnom prostoru. Da bi savladao obranu Bihaća, Zach je morao prethodno osvojiti brdo Debeljaču (trigonometrijska točka - tt 319) koja se nalazi jugozapadno od Bihaća, kao dominantnu i geostrateški važnu kotu s koje se kontrolira okolni prostor, osobito Bihać. Nakon toga trebalo je osvojiti ostale obrambene položaje sjeverno od vrha Debeljače i stalno biti u pripravnosti od mogućih iznenađenja protivničkoga proboja prema granici monarhije.

General Zach sa 72. pješačkom brigadom prelazi granicu 7. rujna i kreće prema objektima obrane Bihaća. Napadne snage podijelio je u dvije kolone: desnu napadnu kolonu činila je 23. pješačka pukovnija, koja je imala zadaću da pokretom od sela Veliki i Mali Skočaj napadne jake protivničke položaje koji su bili postavljeni na brdu Debeljači i bočnim obroncima. Te je položaje branilo oko 1500 ustanika stacioniranih u

52 C. Schmarda, Kurzgefasste Geschichte des k.u.k. Otočaner Infanterie-Regiment Graf Jellačić Nr. 79, str. 57.

53 Utvrda sjeveroistočno od Zavalja uz cestu prema Bihaću.

54 Danzer's Armee-Zeitung, br. 51/52, Beč, 21. prosinca 1911., str. 16-25. 
dvije utvrde i okolnim rovovima. Lijeva kolona, koju su činile dvije pričuvne bojne 79. pješačke pukovnije iz Otočca, imala je zadaću krenuti prema selu Žegar, te osvojiti selo i tursku carinarnicu s uzvisinama istočno iznad sela (dio Somišlja). Procjenjuje se da je na tom pravcu bilo između 600 i 800 ustanika. Ličani su prethodno morali marširati po noći i po krševitu terenu iz područja kod Ličkog Petrova Sela preko Baljevca do polaznih položaja kod sela Vedropolja i odatle krenuti poljem uz Panjački potok u pravcu sela Žegara. Time su morali pokrivati veoma veliko područje kako bi izbjegli protivničke protuudare, osobito iz sela Izačić. Žegar je za obranu imao povoljan teren, posebno uzvisine Križova ${ }^{55}$ i Somišlje i time je imao prednost nad napadnim

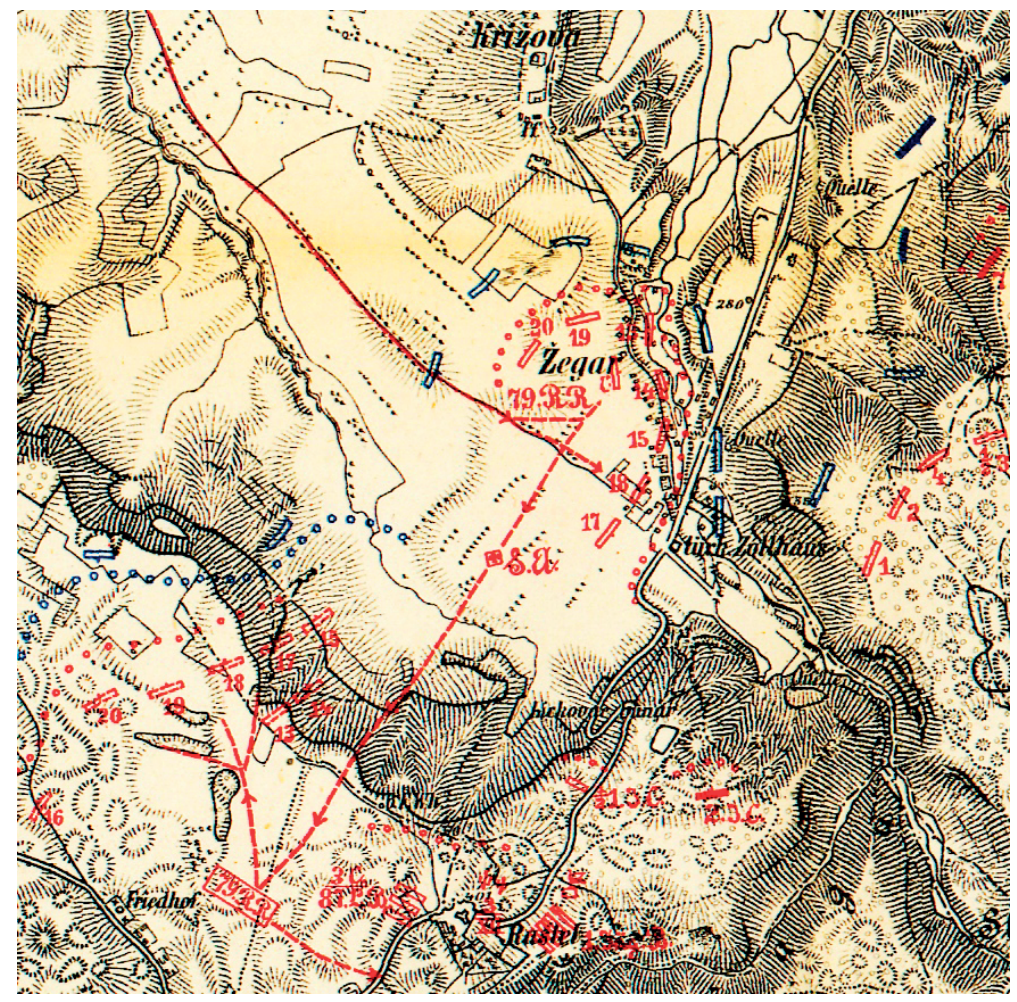

Sl. 8. Borbe 79. pješačke pukovnije (crveno), njihov dolazak od Vedropolja, položaji tijekom borbi u odnosu na ustanike (plavo) i povlačenje prema Zavalju i Raštelu (Izvor: Die Occupation Bosniens und der Herzegovina durch K.K. Truppen im Jahre 1878, nach autentischen Quellen, Tafel XIIIa).

55 Današnja uzvisina Križ, tt 272. 
snagama. Pričuvu su sačinjavale 1 . lovačka bojna, tri satnije 87 . domobranske bojne (Landwehr) i dijelovi 12. topničke pukovnije. ${ }^{56}$

Tijekom 7. rujna u 5 sati ujutro počinju žestoke borbe na pravcu napada Otočana, često uz uporabu bajuneta u bliskim borbama u rovovima, kućama i okolnim uzvisinama iznad sela. Napadne snage u početku osvajaju prednje rovove, ali zbog jake protivničke vatre s okolnih uzvisina koje dominiraju napadnim prostorom, posebno s lijevih bočnih točaka iz Križove, ne uspijevaju osvojiti tursku carinarnicu, župni stan i groblje. Snage pukovnije našle su se u poluokruženju pod snažnom protivničkom vatrom koja je prouzročila velike gubitke.

Treba napomenuti da je istovremeno 23. pješačka pukovnija uspjela osvojiti vrh Debeljače i izbiti na sjeverne obronke prema Bihaću i zapadne obronke iznad Žegara i tu se morala zaustaviti zbog poteškoća oko proboja lijeve kolone. Napadnim snagama toga dana akciju je ometala i gusta magla zbog koje je došlo do velikih problema oko djelovanja ali i upravljanja topničkom vatrom, tako da su zbog toga nastali gubitci od "prijateljske vatre", odnosno od djelovanja vlastitog topništva. ${ }^{57} \mathrm{Zbog}$ nemogućnosti daljnjeg napredovanja i velikih gubitaka general Zach u sumrak istoga dana odluči prekinuti djelovanja kod Zegara i povući 79. pješačku pukovniju na uzvisine kod sela Zavalja, a dio snaga 23. pješačke pukovnije ostao je u blokadi na brdu Debeljača. Čitavo vrijeme povlačenja prema Zavalju 79. pukovnija bila je pod stalnom vatrom ustanika sa sjeverozapada tako da su se morale voditi iscrpljujuće susretne borbe uza značajne gubitke. Veliku pomoć tijekom izvlačenja pružila je 87. domobranska (Landwehr) bojna iz Zagreba, topništvo s Raštela i 1. lovačka bojna. Situacija se dodatno zakomplicirala kada je tijekom borbi iz sela Izačić u Zavalje stigla ustanička skupina od oko 250 osoba s nakanom da uđu u područje monarhije i time u zaleđe Zachovoj brigadi, što je moglo imati katastrofalne posljedice. Taj je pokušaj spriječila hrvatska 87. domobranska bojna koja je tu skupinu uspjela neutralizirati. ${ }^{58}$ Treba napomenuti da je 79. pukovnija dolaskom u Zavalje morala biti razmještena u polukružnoj obrani sjeverozapadno od zavaljskoga groblja

56 Die Occupation Bosniens und der Herzegovina durch K.K. Truppen im Jahre 1878, nach autentischen Quellen, str. 576-584.

57 Danzer's Armee-Zeitung, br. 51/52, Beč, 21. prosinca 1911., str. 16-25.

58 M. Mandić, Povijest okupacije Bosne i Hercegovine 1878, str. 86. 
i sa snagama 87. domobranske bojne, razmještene kod Raštela, organizirati veoma aktivnu obranu od brojnih ustanika koji su joj prijetili.

$\mathrm{U}$ ovim aktivnostima Zachova brigada imala je iznimno velike gubitke: 554 vojnika, od toga 101 mrtvih (tri časnika), 418 ranjenih (18 časnika) i 35 nestalih. Najveći udio gubitaka imala je lička 79. pješačka pukovnija s 317 vojnika izbačenih iz stroja, od toga 65 poginulih. I 23. pješačka pukovnija imala je teške gubitke od 225 pripadnika. ${ }^{59}$

Stradali su brojni časnici i dočasnici. Poginuli su zapovjednik bojne satnik (kapetan) Steyskal, satnik Napijalo i pričuvni poručnik Holm, natporučnik Munk zadobio je ranu u grudi od koje je ubrzo umro, natporučnik Đuro Trbuhović zadobio je hitac kroz bedrene kosti, satnik Damjan Grujičić zadobio je 14 rana ali je nastavio borbu i pomogao ranjenom dočasniku Tomljenoviću da se izvuče na sigurno ${ }^{60}$ Zbog toga je dobio srebrnu medalju za hrabrost druge klase. ${ }^{61} \mathrm{Ra}-$ njeni su još zapovjednik pukovnije potpukovnik Kokotović, satnici Balaško, Grujičić, Löhnert te poručnici Munk i Glaser. ${ }^{62}$

Istovremeno se okupila veća skupina ustanika kod sela Leskovca i Prosičenog Kamena na Korani, koja se nalazi sjeverno od Bihaća, s ciljem napada na granicu Monarhije i stvaranja pomutnje napadnih snaga. Tako 8. rujna, za vrijeme bitke kod Žegara, skupina od oko 600 ljudi napada predstraže 12. lovačke bojne te 88 . hrvatske domobranske bojne koje su ih uspjele odbaciti. ${ }^{63} \mathrm{Na}$ uzvisinama kod Zavalja general Zach grupirao je skupinu za novi napad pod zapovjedništvom bojnika Pokornya, koju su sačinjavali preživjeli vojnici iz 1. lovačke bojne i 79. pješačke pukovnije s ciljem da se oslobodi blokirano ljudstvo 23. pješačke pukovnije na brdu Debeljača, koja je tamo trpjela snažne napade i velike gubitke. ${ }^{64}$

59 Die Occupation Bosniens und der Herzegovina durch K.K. Truppen im Jahre 1878, nach autentischen Quellen, Prilog 12.

60 Österreichisches Staatsarchiv (ÖeStA) - Kriegsarchiv (KA), Wien, ABA (Alte Belohnungsakten), Konsignacija za IR79, 1878/79, kutija 69.

61 C. Schmarda, Kurzgefasste Geschichte des k.u.k. Otočaner Infanterie-Regiment Graf Jellačić Nr. 79, str. 60. ÖeStA - KA, Wien, ABA, Konsignacija za IR79, 1878/79, kutija 69.

62 Die Occupation Bosniens und der Herzegovina durch K.K. Truppen im Jahre 1878, nach autentischen Quellen, str. 584.

63 M. Mandić, Povijest okupacije Bosne i Hercegovine 1878, str. 87.

64 C. Schmarda, Kurzgefasste Geschichte des k.u.k. Otočaner Infanterie-Regiment Graf Jellačić Nr. 79, str. 60. 


\subsection{Borbe tijekom 18. rujna}

Ubrzo se stanje značajno mijenja. Da bi ojačali napadne snage za osvajanje Bihaća, tijekom 10. rujna na ovo područje dolazi 28. pješačka brigada iz 14. pješačke divizije ${ }^{65}$ pod zapovjedništvom general bojnika Rheinländera koja je prethodno bila razmještena u Slunju, Ljeskovcu, Furjanu i Lađevcu. Od ove dvije brigade ustrojena je divizija, a Rheinländer preuzima divizijsko zapovjedništvo. Sljedećih dana provode se pripreme za napad. U međuvremenu je iz Karlovca pristigla veća količina streljiva, a Otočačka pukovnija popunjena je tijekom 13. rujna novim ljudstvom. Isti dan u 16 sati poslijepodne, general Rheinländer sazvao je zapovjednike postrojbi i dao im je usmenu zapovijed za napad. Otočačka pukovnija dobila je zadaću da nakon popune ljudstvom sa svojih šest i dvije satnije (čete) iz 23. pukovnije osvoji dvije utvrde na uzvisini Debeljača, dok su dvije satnije bile namijenjene za zaštitu skladišta streljiva. Napadu je trebala prethoditi snažna topnička priprema. Udružene brigade generala Zacha i Rheinländera započele su 15. rujna odlučni boj s ustanicima, u početku bez djelovanja Otočačke pukovnije koja se još uvijek oporavljala od prethodnih borbi. Najteže borbe vode se kod sela Izačić i Križove u kojima sudjeluje 28. pješačka brigada, a 72. pješačka brigada djeluje kod Žegara i Debeljače i na spoju kod Križove. Isti dan ulazi 76. pričuvna pješačka pukovnija u selo Izačić kako bi tim postupkom spriječila novi eventualni proboj ustanika prema granici. Nakon pada Izačića padaju i susjedna sela (Vikić i druga) čime su rastjerane snage od oko 800 ustanika, koje su se preko sela Papara približile selu Baljevcu, te tamo počele paliti kuće i sjenike. Istodobno 23. pješačka pukovnija i 1 . lovačka bojna izbijaju do protivničkih položaja kod Žegara, a dijelovi 88 . hrvatske domobranske bojne upućeni su prema Ljeskovcu i Prosičenom Kamenu da tamo vežu na sebe dio ustaničkih snaga i time rasterete otpor kod Bihaća. Ukupni gubitci tijekom 15. rujna: 61 poginuli i ranjeni, a "Jelačićevci" imaju dva ranjena kod Križove. ${ }^{66}$

65 U brigadi su bile: 48. linijska (Velika Kaniža-Nagykanizsa, Ugarska), 76. pričuvna pješačka pukovnija (Šopron-Ödenburg, Ugarska) i 12. lovačka bojna iz Kolina, Češka (Die Occupation Bosniens und der Herzegovina durch K.K. Truppen im Jahre 1878, nach autentischen Quellen, str. 9).

66 M. Mandić, Povijest okupacije Bosne i Hercegovine 1878, str. 87; Die Occupation Bosniens und der Herzegovina durch K.K. Truppen im Jahre 1878, nach autentischen Quellen, Prilog 12. 
Tijekom 16. i 17. rujna provode se završne pripreme za napad na Debeljaču, prednje i bočne uzvisine Somišlje i Križova i na sam Bihać. Za napad su raspoložive snage grupirane u dvije kolone: lijevu i desnu. "Jelačićevci" su u sastavu lijeve kolone i kreću od Raštela prema rovovima na uzvisini Somišlje i Križova i turskoj carinarnici. Te je snage činila IV. bojna ${ }^{67}$

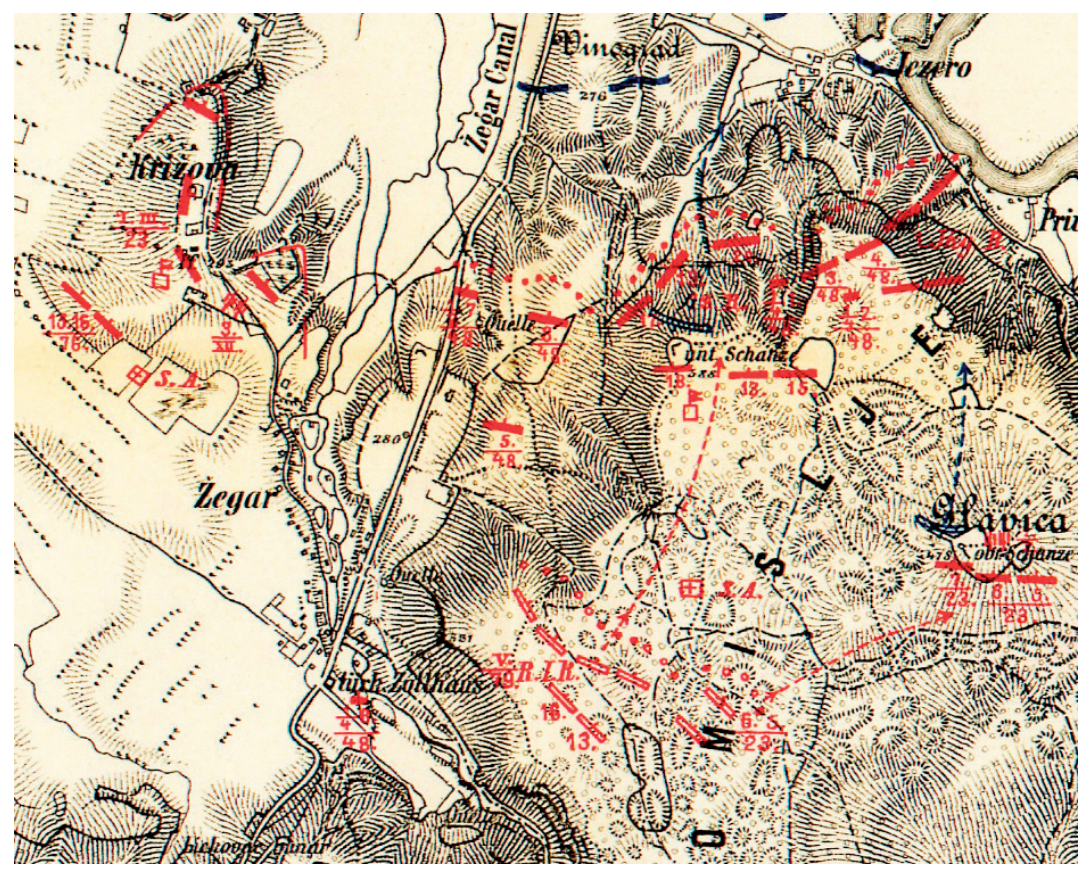

S1. 9. Borbe 79. pješačke pukovnije (crveno) na zapadnim padinama Somišlja (Debeljače) iznad turske carinarnice i njihovo napredovanje prema sjeveru zajedno s 23. i 48. pješačkom pukovnijom (Izvor: Die Occupation Bosniens und der Herzegovina durch K.K. Truppen im Jahre 1878, nach autentischen Quellen, Tafel XIIIc)

Združene snage, 18. rujna u 8 sati ujutro, uza snažnu topničku potporu, izbile su ispred turske carinarnice koju su ubrzo osvojili. Tu je zapovjednik pukovnije potpukovnik Kokotović rasporedio ljudstvo za napad na protivničke rovove i krenuo prema naprijed. Na položaje kod carinarnice stižu dijelovi 48. pukovnije. Kokotović je oformio borbene skupine Otočana pod zapovjedništvom pričuvnoga poručnika Ludviga Toplaka. Tijekom napredovanja dvije skupine izbile su u

67 Die Occupation Bosniens und der Herzegovina durch K.K. Truppen im Jahre 1878, nach autentischen Quellen, str. 605. 
10,15 sati ispred protivničkih prednjih rovova, koji su se nalazili iznad izvora u Žegaru. Toplak je kao prethodnica izgubio kontakt s glavnim snagama koje su se našle pod snažnom vatrom ustanika. Bez obzira na to Toplak je nastavio napad sa svojim snagama prema rovovima $u$ koje je ušao nakon bliske borbe usput zarobivši bogat plijen.

Ubrzo se ustanici organiziraju i napadaju s tri strane radi povrata izgubljenih položaja. Toplaku u pomoć dolazi poručnik Đuro Miljuš sa svojom skupinom te uspijevaju odbiti napad. Da bi spriječio daljnje protivničko napredovanje, u pomoć dolazi i peta bojna pod zapovjedništvom bojnika Brauna koji je u tim borbama smrtno ranjen, a zapovjedništvo bojne preuzima natporučnik Grozdanić. Pod njegovim zapovjedništvom ustanici su odbačeni prema Uni, odnosno, prema Bihaću. Istovremeno četvrta bojna Otočana uz prethodnu snažnu topničku pripremu izbija iznad izvora u Žegaru i time Ličani ispunjavaju svoju zadaću. Ove snage ojačavaju dijelovi 48. pukovnije koji usput posjedaju i položaje iznad izvora i time zatvaraju pristup prema Debeljači (Somišlju). U međuvremenu je 23. pješačka pukovnija s 1. lovačkom bojnom krenula prema vrhu Debeljače koju uspijeva zauzeti. Ubrzo na vrh pristižu i topnici koji nesmetano djeluju na Bihać, a pješaci kreću prema Bihaću. Osvajanjem dominantnih uzvisina napadne snage stekle su važnu prednost nad obranom Bihaća. Kad je s okolnih uzvisina zaprijetila snažna i destruktivna topnička paljba po Bihaću, tijekom 19. rujna turski časnici Nuri-beg i Hasanaga dolaze u Zavalje i ugovaraju predaju Bihaća.

Ukupni gubitak austrougarskih snaga pri napadu na Bihać od 18. rujna iznosio je: 11 mrtvih, 165 ranjenih i 1 nestali, od toga pet časnika. "Jelačićevci" imaju dva poginula i 97 ranjenih. ${ }^{68}$ Nakon bitke na okolnom području pronađeno je 217 leševa ustanika. Računa se da su s ranjenicima ukupni gubitci ustanika iznosili između 600 i 800 ljudi. Te je gubitke potvrdio i general Zach i pohvalio ličku pukovniju za uspješne borbe. Prilikom završnoga napada Ličani su ostali bez streljiva jer su imali samo 20-25 naboja po puški. Ustanici pobjegoše tijekom 19. rujna prema Petrovcu i u sjevernu Krajinu ostavivši iza sebe pet topova, mnogo oružja i streljiva. U Bihać su ušle austrougarske snage na čelu s generalima Zachom i Rheinländerom i 23. pješačkom pukovnijom uz Radetzky marš.

Tijekom 20. rujna 28 turskih časnika i 88 tvrđavnih topnika došlo je u Zavalje, gdje su zadržani do 23. rujna kako bi uredili svoje dugove

68 Isto, Prilog 12. 
prema židovskim trgovcima iz Bihaća. Nakon toga su u pratnji obitelji, uključujući Nuri-begov harem, otpravljeni preko Slunja za Karlovac. ${ }^{69}$

Pacifikacija Krajine između Une i hrvatske granice povjerena je generalu Rheinländeru, koji je planirao snažnim udarom skršiti i zadnji otpor ustanika. Nakon pada Bihaća Rheinländer kreće 25. rujna prema jugoistoku, dakle onim smjerom kojim su pobjegli bihaćki ustanici. Namjera mu je bila da se spoji sa snagama iz pravca Banja Luke, te pacificira ustanička mjesta, naročito Petrovac, kao središta za sakupljanje ustanika. Tijekom 4. listopada krenuo je prema selu Peć. Putem mu je dojavljeno da su se ustanici iz Vrnograča, Bužima i Jezerskoga skupili oko Peći, te tijekom 6. listopada zaposjeli uzvisinu Debelo brdo (tt $341 \mathrm{~m}$ ). Tijekom 7. listopada pada selo Peć i Pecka gora koja se nalazi sjeverno od Peći. U naknadnim borbama zauzet je Ključ.

Gubitak u ovim bojevima bio je velik, osobito 6. listopada: $53 \mathrm{mrtva}$ i 205 ranjenih, od toga 5 časnika. Zatim Rheinländer osvaja i susjedna mjesta Podzvizd, Vrnograč, a Bužim se dragovoljno predao. Tijekom 20. listopada još je otpor pružala tvrđava u Kladuši, koju je 1. lovačka bojna prisilila na predaju.

Padom Bihaća došlo je do šoka među ustanicima na širem području čime je olakšan ulaz austrougarskih snaga u ostala važnija mjesta u Krajini. Tako je hrvatska 83. domobranska pješačka brigada pod vodstvom pukovnika Musulina bez otpora ušla u Kulen-Vakuf i ostala okolna mjesta. U zapadnoj Bosni još se žestoko branilo Livno koje je palo 28. listopada čime su ustanici izgubili najvažnije uporište u zapadnoj Bosni, a padom Bihaća i Kladuše i u Krajini. Time je završila okupacija čitave Bosne i Hercegovine koja je potrajala gotovo tri mjeseca. Austro-Ugarska je izgubila ukupno 5198 vojnika u ovim bojevima, od toga je poginulo 946, ranjeno 3975, nestalo 277 vojnika. Gubitci ustanika nisu poznati. ${ }^{70}$

Tijekom 19. listopada car je odao priznanje svim sudionicima okupacije za njihovu veliku požrtvovnost, ustrajnost, vjernost i disciplinu, te sve pretrpljene patnje koje su podnijeli po lošem vremenu i lošim putevima uz velike oskudice koje su pretrpjeli. ${ }^{71}$

69 C. Schmarda, Kurzgefasste Geschichte des k.u.k. Otočaner Infanterie-Regiment Graf Jellačić Nr. 79, str. 63; Danzer's Armee-Zeitung, br. 51/52, Beč, 21. prosinca 1911., str. 16-25.

70 M. Mandić, Povijest okupacije Bosne i Hercegovine 1878, str. 79; Die Occupation Bosniens und der Herzegovina durch K.K. Truppen im Jahre 1878, nach autentischen Quellen, Prilog 12.

71 M. Mandić, Povijest okupacije Bosne i Hercegovine 1878, str. 88-90. 
U borbama za Bihać i okolicu s austrougarske strane izbačeno je iz stroja 918 vojnika, od toga 136 poginulih. Ostali su "mnogi grobovi, nakićeni spomenici, pod Debeljačom i kod Žegara tužni su svjedoci krvave borbe kod Bihaća", navodi Radoslav Lopašić u svome djelu "Bihać i Bihaćka krajina". Književnik Janko Leskovar navodi da na "brdu Somišlju bijaše ogroman spomenik generalu Leggiju (?) koji je tamo pogođen tanetom iz turskog topa. Kod Žegara stajaše i drugi spomenik 79. pješačke pukovnije. Spomenik na Somišlju je nakon Drugog svjetskog rata nestao, a onaj u Žegaru je zapušten".72

Tijekom 30. listopada dolazi u Zavalje general Josip Filipović iz Zagreba, da bi idućega dana bio svečano primljen i u Bihaću. Tu je održao govor na hrvatskom jeziku. Navečer je u Zavalju organizirao banket za časnike. ${ }^{73}$

Budući da su osim vojnika prisilno mobilizirane brojne zaprežne životinje, ostalo je mnogo neobrađenih polja zbog čega je stanovništvo teško oskudijevalo na širokom području mobilizacije. ${ }^{74}$

\subsection{Odličja pripadnika 79. pričuvne pješačke pukovnije}

Nakon borbi zbog iznimnih zasluga odlikovani su pojedini pripadnici IV. i V. bojne "Ličke" pukovnije:

Redom željezne krune (Österreichisch-kaiserlicher Orden der Eisernen Krone 3 classe): pukovnik (Oberst) Julije Kristijanović, potpukovnik (Oberstlieutenant) Aleksandar Kokotović i pričuvni poručnik Toplak. Zaslužni križ (Verdienstkreuz): satnik Samuel Vitas, natporučnik Demić, poručnik Miljuš i pričuvni poručnik Polanec.

Značajan broj vojnika predložen je za srebrne medalje za hrabrost. Vrlo su zanimljiva obrazloženja prijedloga iz kojih se vide zasluge pojedinih vojnika, časnika i dočasnika: ${ }^{75}$

72 Ivan Dujmović, Povijest zavaljske župe, Udruga umjetnika "August Šenoa", Zagreb, 1999., str. 82-83.

73 Danzer's Armee-Zeitung, br. 51/52, Beč, 21. prosinca 1911., str. 16-25.

74 T. Oršolić, Sudjelovanje dalmatinskih postrojbi u zaposjedanju Bosne i Hercegovine 1878., str. 293.

75 ÖeStA - KA, Wien, ABA, Konsignacija za IR79, 1878/79, kutija 69. Konsignaciju o vojnicima sačinio je pukovnik Kokotović u Zavalju 12. rujna 1878. 


\begin{tabular}{|c|c|c|c|}
\hline Satnija & Čin & Ime i prezime & Obrazloženje \\
\hline \multirow[t]{3}{*}{13.} & narednik & Stjepan Mašić & $\begin{array}{l}\text { Pri napredovanju svojim mirom i ohrabru- } \\
\text { jućim riječima vrlo dobro djelovao, kod ju- } \\
\text { riša odlučnim postupkom povukao ljude za } \\
\text { sobom. Pri povlačenju pokrivao lijevo krilo. }\end{array}$ \\
\hline & vodnik & Ivan Batinić & $\begin{array}{l}\text { Spretno i odvažno vodeći svoju skupinu, bio } \\
\text { je ranjen u obraz, dao si je za nuždu previti } \\
\text { ranu i požurio natrag na prvu borbenu crtu, } \\
\text { gdje je neprekidno vodio svoju skupinu hra- } \\
\text { bro i u uzornom redu. }\end{array}$ \\
\hline & razvodnik & $\begin{array}{l}\text { Nikola pl. } \\
\text { Oklobdžija }\end{array}$ & $\begin{array}{l}\text { Iznimnom osobnom hrabrošću bio je dobar } \\
\text { primjer momčadi kod davanja bočne zaštite } \\
\text { skupini poručnika Toplaka, pri čemu se odli- } \\
\text { kovao dobrim orijentiranjem na nepreglednu } \\
\text { terenu. }\end{array}$ \\
\hline \multirow[t]{3}{*}{14.} & \multirow[t]{2}{*}{ desetnici } & Ilija Beslać & $\begin{array}{l}\text { Iskazao se posebnom hrabrošću pri juri- } \\
\text { šu na Žegar; nakon pogibije natporučnika } \\
\text { Munka vodio je vod odvažno i spretno sve } \\
\text { do kraja sukoba. }\end{array}$ \\
\hline & & Maksim Brkić & $\begin{array}{l}\text { Tijekom borbe u selu stalno na prvoj crti; } \\
\text { hrabrim držanjem poticao je momčad da } \\
\text { izdrži, s poručnikom Toplakom je ranjenog } \\
\text { pričuvnog zapovjednika pukovnije izvukao } \\
\text { iz borbene crte. To je posvjedočio potpu- } \\
\text { kovnik Kokotović, pričuvni zapovjednik } \\
\text { pukovnije. }\end{array}$ \\
\hline & pješak & Dane Šulentić & $\begin{array}{l}\text { Kod ponovnoga napada na Žegar, jednog je } \\
\text { pješaka koji je htio zaostati, bajunetom na- } \\
\text { tjerao u njegovu jedinicu, i uopće se pokazao } \\
\text { kao vrlo odvažan i hrabar. }\end{array}$ \\
\hline \multirow[t]{5}{*}{15.} & vodnik & Stanislav Selak & $\begin{array}{l}\text { Kod juriša na Žegar istaknuo se obazrivim } \\
\text { i hrabrim vođenjem svojeg roja; u samom } \\
\text { selu okupio je vod i izveo sjajan napad na } \\
\text { kuću zauzetu od neprijatelja i - iako odba- } \\
\text { čen - nije izgubio hrabrost, ponovo je okupio } \\
\text { momčad i ohrabrio ju na ponovni napad; pri } \\
\text { povlačenju, iako ranjen u nogu i dalje se dr- } \\
\text { žao iznimno hrabro. }\end{array}$ \\
\hline & pješak & Stjepan Lončar & $\begin{array}{l}\text { Tijekom cijele bitke dobrovoljno se borio } \\
\text { na prvoj crti i svojom zadivljujućom hra- } \\
\text { brošću iznimno povoljno djelovao je na } \\
\text { momčad. }\end{array}$ \\
\hline & \multirow[t]{2}{*}{ razvodnici } & Dane Škorić & \multirow{2}{*}{$\begin{array}{l}\text { Kako pri jurišu na Žegar, tako i tijekom } \\
\text { cijelog sukoba, svojim uzornim hrabrim } \\
\text { držanjem izvršili su odlučujući utjecaj na } \\
\text { momčad. }\end{array}$} \\
\hline & & Filip Cvjetićanin & \\
\hline & narednik & Anton Ježić & $\begin{array}{l}\text { Odlikovao se spretnim vođenjem svog } \\
\text { voda i iznimnom osobnom hrabrošću kod } \\
\text { juriša na Žegar; lakše ranjen na prvoj bor- } \\
\text { benoj crti. }\end{array}$ \\
\hline
\end{tabular}




\begin{tabular}{|c|c|c|c|}
\hline \multirow[t]{4}{*}{16.} & narednik & $\begin{array}{l}\text { Emanuel } \\
\text { Živković }\end{array}$ & $\begin{array}{l}\text { Kod juriša na Žegar istaknuo se uzornim } \\
\text { vođenjem momčadi i osobnom hrabrošću. } \\
\text { Kasnije, kod povlačenja pukovnije, učinio } \\
\text { je sve kako bi se satnija brzo sredila. }\end{array}$ \\
\hline & vodnik & Emanuel Ličina & $\begin{array}{l}\text { Kod juriša na Žegar istaknuo se velikom } \\
\text { hladnokrvnošću i hrabrošću. }\end{array}$ \\
\hline & desetnik & Toma Jančić & $\begin{array}{l}\text { Svojom osobnom primjernom hrabrošću } \\
\text { bitno je doprinio brzom sređivanju satnije. }\end{array}$ \\
\hline & pješak & Filip Palić & $\begin{array}{l}\text { Kod juriša na Žegar iskazao se posebnom } \\
\text { hrabrošću. }\end{array}$ \\
\hline \multirow[t]{5}{*}{17.} & vodnik & Josip Barković & $\begin{array}{l}\text { Tijekom cijelog sukoba, i čak nakon ranja- } \\
\text { vanja, ponašao se veoma energično i hrabro } \\
\text { i poslužio kao lijep primjer za ostalu mom- } \\
\text { čad. }\end{array}$ \\
\hline & razvodnik & Obrad Mileusnić & \multirow{4}{*}{$\begin{array}{l}\text { Tijekom borbe pokazali su svake pohva- } \\
\text { le vrijedno držanje i djelovali su kao uzor } \\
\text { ostalim vojnicima. }\end{array}$} \\
\hline & \multirow[t]{3}{*}{ pješaci } & $\begin{array}{l}\text { Nikola } \\
\text { Majstorović }\end{array}$ & \\
\hline & & Ivan Malović & \\
\hline & & Ilija Ličina & \\
\hline \multirow[t]{2}{*}{18.} & \multirow[t]{2}{*}{ vodnici } & Pavao Binički & $\begin{array}{l}\text { Kod povlačenja, svojom izvanrednom od- } \\
\text { lučnošću brzo je okupio } 4 \text {. vod i potaknuti } \\
\text { ga na nepopustljivi otpor. }\end{array}$ \\
\hline & & Josip Beširević & $\begin{array}{l}\text { U posljednjoj fazi bitke, ruba šume, ohra- } \\
\text { brujućim nagovorom i vlastitim odlučnim } \\
\text { primjerom potaknuo je izmučenu momčad } \\
\text { na energično napredovanje. }\end{array}$ \\
\hline \multirow[t]{2}{*}{19.} & $\begin{array}{l}\text { računarski } \\
\text { narednik }\end{array}$ & Ivan Tomljenović & $\begin{array}{l}\text { Nakon što je u Zavalju saznao o ranjavanju } \\
\text { zapovjednika njegove satnije (čete), natpo- } \\
\text { ručnika Trbuhovića, pojurio je na borbenu } \\
\text { crtu, kako bi ga pronašao; to mu je kasnije } \\
\text { i uspjelo. }\end{array}$ \\
\hline & vodnik & Ilija Blanuša & $\begin{array}{l}\text { Uzornim vođenjem svoga voda i hrabrom } \\
\text { nepopustljivošću lijevoga krila, odbio ne- } \\
\text { prijateljski proboj, a i u zadnjoj fazi bitke, } \\
\text { kod ruba šume držao se odvažno. }\end{array}$ \\
\hline
\end{tabular}




\begin{tabular}{|c|c|c|c|}
\hline \multirow[t]{4}{*}{20.} & $\begin{array}{l}\text { kadet-vod- } \\
\text { nik } \\
\text { titularni } \\
\text { narednik }\end{array}$ & Gabrijel Šašić & $\begin{array}{l}\text { Kao zastavnik svojim je ohrabrujućim go- } \\
\text { vorima i velikom hladnokrvnošću pobudio } \\
\text { momčad i zatražio nužnu obranu zastave } \\
\text { ako bi se ukazala potreba. }\end{array}$ \\
\hline & $\begin{array}{l}\text { vodnik } \\
\text { titularni } \\
\text { narednik }\end{array}$ & Franjo Žaretić & $\begin{array}{l}\text { Sa } 16 \text { ljudi iz satnije ranjenoga satnijskog } \\
\text { zapovjednika natporučnika Đure Trbuho- } \\
\text { vića i ostalih } 25 \text { ranjenih, svojim iznimno } \\
\text { odlučnim i hrabrim postupanjem spasio ih } \\
\text { je od zarobljavanja i masakra. }\end{array}$ \\
\hline & \multirow[t]{2}{*}{ narednici } & Mihovil Kardaš & $\begin{array}{l}\text { Iznimno neustrašiv i hrabar, pokušao je s } \\
\text { velikom požrtvovnošću okupiti četu koja } \\
\text { je ranjavanjem natporučnika Trbuhovića } \\
\text { ostala bez vodstva, i potaknuti je na tvrdo- } \\
\text { korni otpor - to mu je i uspjelo. A i u za- } \\
\text { dnjoj fazi bitke, kod ruba šume, odvažno se } \\
\text { držao. }\end{array}$ \\
\hline & & Petar Ivanović & $\begin{array}{l}\text { Unatoč veoma teškoj povredi, znao je svojim } \\
\text { neustrašivim i uzornim držanjem svoj vod - } \\
\text { podsjećajući ga na čast pukovnije i na povje- } \\
\text { renje kojeg su u njoj uživali - tako raspaliti i } \\
\text { ohrabriti, da je daleko nadmašio svoju prvo- } \\
\text { bitnu zadaću; još je jednom ranjen. }\end{array}$ \\
\hline
\end{tabular}

\section{Zaključak}

Francuski povjesničar Pierre Nora, jedan od utemeljitelja ideje kulture sjećanja kroz obnovu zapuštenih spomen obilježja poginulima u Prvom svjetskom ratu, kazao je: "O sjećanju neprestance govorimo, jer ga više nemamo." Mjesta sjećanja ili lieux de mémoire su ona mjesta gdje se "pamćenje kristalizira i izlučuje"; mjesta gdje se iscrpljen kapital kolektivnoga pamćenja kondenzira i izražava. Tako je okupacija Bosne i Hercegovine nestala iz našega povijesnog sjećanja, iako je imala dalekosežne političke posljedice na ovo i šire područje. Iznimni gubitci i stradanja obiju strana, te političke posljedice nastale nakon okupacije, zahtijevaju iznimne napore da se ovi događaji temeljito sagledaju i istraže na osnovi novih spoznaja. Okupacija Bosne i Hercegovine nastala je nakon burnih i zamršenih političkih događanja toga vremena i kao takva imala je vrlo dinamične učinke u srazu dviju sasvim različitih vojnih koncepcija: organizirane austrougarske vojske i ustanika koji su u početku imali visok moral, ali i nedostatak vojnog ustroja i resursa potrebnih za konačnu vojnu pobjedu. To se posebno vidi u početnim borbama kod Bihaća kada ustanici uspijevaju zaustaviti proboj prema Bihaću i odbiti napadne snage uz velike žrtve, primoravši ih na dopremu značajnih ojačanja na ovo područje. 


\section{People from Lika in the occupation of Bosnia and Herzegovina in 1878}

\section{Summary}

Occupation of Bosnia and Herzegovina in 1878, which completely changed the political state of this Ottoman province by using the military forces and at the same time caused numerous victims for both belligerents, is somehow forgotten although it was a very important historical event of our wider region. That was a big tragedy for some citizens of Bosnia and Herzegovina and for the others happiness because they became independent on Ottoman rule. Although all these events happened more than 140 years ago, their consequences are still felt and we shall not understand them if we do not get acquainted with that period and especially with political circumstances in which all of this happened. We hope that this article, dedicated to a special Croatian Infantry Regiment (K.u.K. 79. Ungarische (croatisches) Otocaner Infaterie-Regiment Graf Jellacic), will enable readers to understand better how this part of Europe was transformed through history. That is especially important because certain nations remember and explain those events in different ways. Thus that tragic period will become a part of our historical memory and better understanding of the presence and future.

Keywords: occupation of Bosnia and Herzegovina in 1878; Bihac; 79th Infantry Regiment Joint Forces "Grof Josip Jellacic" Otocac. 